NBER WORKING PAPER SERIES

\title{
INCENTIVE FEES AND COMPETITION IN PENSION FUNDS: EVIDENCE FROM A REGULATORY EXPERIMENT
}

\author{
Assaf Hamdani \\ Eugene Kandel \\ Yevgeny Mugerman \\ Yishay Yafeh \\ Working Paper 22634 \\ http://www.nber.org/papers/w22634
NATIONAL BUREAU OF ECONOMIC RESEARCH
1050 Massachusetts Avenue
Cambridge, MA 02138
September 2016

This project was supported by the Israel Science Foundation (Grant No. 890/2013) and by the by the I-CORE program of the Planning and Budgeting Committee and the Israel Science Foundation (Grant No. 1821/12). Kandel and Yafeh received financial support from the Krueger Center at the Jerusalem School of Business Administration. We thank Doron Avramov, Michel Habib, Naomi Hausman, Petri Jylha, Beni Lauterbach, Lavi Schiffenbauer, Clemens Sialm, Michael Weisbach and seminar participants at Bar Ilan University, the BI Business School (Oslo), the Conference on Empirical Legal Studies in Europe (CELSE), the CEPR's First Annual Symposium in Financial Economics (London), ESMT (Berlin), FIRS (Lisbon, 2016), the Hebrew University, Harvard Law School (JLFA conference), the NBER, and UC Berkeley for helpful comments and suggestions. We are also grateful to Ran Cohen, Izik Daniel, Assaf Hasson, Orry Kaz, Yaniv Makdoosi, Eyal Malka, Roma Poberejsky, Evyatar Sadeh, Noa Shukrun and Tomer Yafeh for outstanding research assistance. The views expressed herein are those of the authors and do not necessarily reflect the views of the National Bureau of Economic Research.

NBER working papers are circulated for discussion and comment purposes. They have not been peer-reviewed or been subject to the review by the NBER Board of Directors that accompanies official NBER publications.

(C) 2016 by Assaf Hamdani, Eugene Kandel, Yevgeny Mugerman, and Yishay Yafeh. All rights reserved. Short sections of text, not to exceed two paragraphs, may be quoted without explicit permission provided that full credit, including (C) notice, is given to the source. 
Incentive Fees and Competition in Pension Funds: Evidence from a Regulatory Experiment Assaf Hamdani, Eugene Kandel, Yevgeny Mugerman, and Yishay Yafeh

NBER Working Paper No. 22634

September 2016

JEL No. G22,G23,G3

\begin{abstract}
$\underline{\text { ABSTRACT }}$
Concerned with excessive risk taking, regulators worldwide generally prohibit private pension funds from charging performance-based fees. Instead, the premise underlying the regulation of private pension schemes (and other retail-oriented funds) is that competition among fund managers should provide them with the adequate incentives to make investment decisions that would serve their clients' long-term interests. Using a regulatory experiment from Israel, we compare the effects of incentive fees and competition on the performance of three exogenouslygiven types of long-term savings schemes operated by the same management companies: (i) funds with performance-based fees, facing no competition; (ii) funds with AUM-based fees, facing low competitive pressure; and (iii) funds with AUM-based fees, operating in a highly competitive environment. Our main result is that funds with performance-based fees exhibit significantly higher risk-adjusted returns than other funds, but are not necessarily riskier (that depends on the measure of risk used). By contrast, we find that competitive pressure leads to poor performance, and conclude that incentives and competition are not perfect substitutes in the retirement savings industry. Our analysis suggests that the pervasive regulatory restrictions on the use of performance-based fees in pension fund management may be costly for savers in the longrun.
\end{abstract}

Assaf Hamdani

Faculty of Law

The Hebrew University, Mount Scopus

Jerusalem 91905, Israel

assaf.hamdani@mail.huji.ac.il

Eugene Kandel

Department of Economics

Hebrew University

Mount Scopus

Jerusalem 91905, Israel

mskandel@mscc.huji.ac.il
Yevgeny Mugerman

School of Business Administration

The Hebrew University

Jerusalem 91905, Israel

mugi@mscc.huji.ac.il

Yishay Yafeh

School of Business Administration

The Hebrew University, Mt. Scopus

Jerusalem 91905, Israel

msyafeh@mscc.huji.ac.il 


\title{
Incentive Fees and Competition in Pension Funds: Evidence from a Regulatory Experiment
}

\author{
This Draft: September 2016 \\ Assaf Hamdani, Eugene Kandel, Yevgeny Mugerman and Yishay Yafeh
}

\begin{abstract}
Concerned with excessive risk taking, regulators worldwide generally prohibit private pension funds from charging performance-based fees. Instead, the premise underlying the regulation of private pension schemes (and other retail-oriented funds) is that competition among fund managers should provide them with the adequate incentives to make investment decisions that would serve their clients' long-term interests. Using a regulatory experiment from Israel, we compare the effects of incentive fees and competition on the performance of three exogenously-given types of long-term savings schemes operated by the same management companies: (i) funds with performance-based fees, facing no competition; (ii) funds with AUM-based fees, facing low competitive pressure; and (iii) funds with AUM-based fees, operating in a highly competitive environment. Our main result is that funds with performance-based fees exhibit significantly higher risk-adjusted returns than other funds, but are not necessarily riskier (that depends on the measure of risk used). By contrast, we find that competitive pressure leads to poor performance, and conclude that incentives and competition are not perfect substitutes in the retirement savings industry. Our analysis suggests that the pervasive regulatory restrictions on the use of performance-based fees in pension fund management may be costly for savers in the long-run.

* Hamdani is at the Faculty of Law, the Hebrew University, and ECGI (assaf.hamdani@mail.huji.ac.il); Kandel is at the Department of Economics, School of Business Administration and the Federmann Center for the Study of Rationality at the Hebrew University, CEPR and ECGI (eukand@gmail.com); Mugerman is at the School of Business Administration the Hebrew University and the College of Management (mugi@huji.ac.il), and Yafeh is from the School of Business Administration, the Hebrew University, CEPR and ECGI (yishay.yafeh@huji.ac.il). This project was supported by the Israel Science Foundation (Grant No. 890/2013) and by the by the I-CORE program of the Planning and Budgeting Committee and the Israel Science Foundation (Grant No. 1821/12). Kandel and Yafeh received financial support from the Krueger Center at the Jerusalem School of Business Administration. We thank Doron Avramov, Michel Habib, Naomi Hausman, Petri Jylha, Beni Lauterbach, Lavi Schiffenbauer, Clemens Sialm, Michael Weisbach and seminar participants at Bar Ilan University, the BI Business School (Oslo), the Conference on Empirical Legal Studies in Europe (CELSE), the CEPR's First Annual Symposium in Financial Economics (London), ESMT (Berlin), FIRS (Lisbon, 2016), the Hebrew University, Harvard Law School (JLFA conference), the NBER, and UC Berkeley for helpful comments and suggestions. We are also grateful to Ran Cohen, Izik Daniel, Assaf Hasson, Orry Kaz, Yaniv Makdoosi, Eyal Malka, Roma Poberejsky, Evyatar Sadeh, Noa Shukrun and Tomer Yafeh for outstanding research assistance.
\end{abstract}




\section{Introduction}

Private retirement savings funds play an increasingly important role around the world. By the end of 2013, retirement funds in the OECD countries held about \$25 trillion of assets under management (OECD, 2014). Moreover, countries are increasingly relying on private pension schemes using the defined-contribution model, where investment risks are borne by savers (OECD, 2013). The well-being of future retirees around the world thus depends on the quality of investment decisions made by fund managers and on the extent to which these managers' incentives are aligned with the long-term interests of their investors-savers.

The academic literature on private retirement savings has focused on the U.S. pension system, where employees generally save through their employer's pension plan. In the case of government and some corporate pension plans, employees have little choice concerning the investment of their savings (Martin, 2014). Other employers' pension plans, however, offer employees a menu of investment options. Employees thus assume responsibility for their retirement savings' investment decisions, and can move their funds from one investment option offered by their employer to another. Savers increasingly invest through mutual funds included in their pension plan, although these funds serve other types of investors as well (Fisch, 2010). Against this background, research has focused on the (poor) quality of individual investor choices and on mutual fund behavior and performance.

In many countries, however, the retirement savings landscape is remarkably different: savers (not employers) choose their own private retirement savings scheme or pension fund. While they can choose among different schemes, savers cannot make specific investment decisions. Rather, they are bound to rely on the professional money managers of their pension funds to make investment decisions on their behalf. Pension fund managers thus have considerable discretion - they make asset allocation decisions as well as security selection decisions within asset classes. While the reliance on money managers may alleviate some of the concerns associated with having individual savers making specific investment decisions, this regulatory setting creates an inherent agency problem between fund managers and savers. Pension fund managers make daily decisions 
with significant long-term effects on savers; their incentives, however, may not be fully aligned with those of their clients.

In this setting, policymakers can use several types of regulatory strategies to align the interests of fund managers with those of savers. First, they can regulate the level and structure of fund fees, including the compensation of individual fund managers. Second, policymakers can determine the intensity of competition between private pension funds by imposing restrictions on the mobility of savers or by adopting measures to facilitate saver choice and reduce the cost of switching pension providers. ${ }^{1}$ Third, policymakers can constrain fund-managers' asset-allocation and other investment decisions, either directly by imposing quantitative limits on investment in certain asset classes (Antolin et. al., 2009), or indirectly by subjecting fund managers to fiduciary duties (Gordon, 1987; Davis, 2002). Finally, regulators can subject fund managers to a variety of corporate governance and disclosure duties.

In this study, we address the first two policy instruments: fee structure and competition. We take advantage of a unique regulatory experiment in Israel that enables us to study the interaction between regulation, fee structure, competition and fund performance. $^{2}$ Specifically, we explore the effect of performance-based fees and competition on fund performance and costs.

What should be the structure of fees paid to private pension funds? A vast principal-agent literature prescribes some degree of performance-based pay for an agent, whose performance depends on her unobserved actions. Indeed, most unregulated money managers, such as venture capital, private equity and hedge funds, normally use performance-based fees. Institutions, endowments or high-net worth individuals, who can freely choose, prefer to invest in actively managed funds whose compensation depends on their performance. Such funds typically receive a significant (around 20\%) fraction of

\footnotetext{
${ }^{1}$ In Italy, for example, there is an ongoing debate over the wisdom of allowing full portability of pension savings, see Moreolo (2015).

${ }^{2}$ We have no data on individual money managers' compensation or their career concerns (e.g., age or experience). We therefore focus on fees paid to the fund management companies and not to the individual managers whom they employ; however, there is a clear link between the two. Even though performancebased pay may exist at the individual fund manager level, it is limited by the fact that fund fees are not related to performance. For a recent study of portfolio manager compensation in the U.S. mutual fund industry, see Ma et al. (2015).
} 
their investors' returns (Gompers and Lerner, 1999; Metrick and Yasuda, 2010; Kandel et al., 2011). ${ }^{3}$ Yet, regulators around the world normally prohibit such incentive fee arrangements in retirement savings schemes and other retail-oriented investment products, such as mutual funds. ${ }^{4}$ Thus, the predominant form of retirement savings (and mutual) fund fees around the world is a fixed percentage of assets under management (AUM). A recent OECD survey identifies only two countries - the Czech Republic and Poland - that allow pension funds to charge fees based on investment returns (OECD, 2011).

The rationale underlying this prohibition is the concern that performance-based fees might lead to excessive risk taking (e.g., Illig, 2007). ${ }^{5}$ Excessive risk-taking by fund managers may present a special concern for retirement savings schemes for two reasons. First, whereas savers normally allocate their savings among different mutual funds, in the setting underlying this paper, a saver's entire retirement portfolio is under the direction of a single private fund (and its managers). Second, as explained earlier, pension fund managers typically have more decision-making power than managers of mutual funds, as they have considerable discretion concerning their portfolio's asset allocation.

By itself, an AUM-based fee structure does not provide adequate incentives for fund managers, as it does not directly relate to the funds' investment returns or cost structure. ${ }^{6}$ However, in an environment of AUM-based fees, the role of motivating funds to ensure savers' long-term interests is assigned to competition among funds (Cooper, 2010). The premise underlying this regime is that funds with better investment returns will attract more investors (inflows), thereby increasing assets under management and fees. According to this logic, competition provides the link between fund performance

\footnotetext{
${ }^{3}$ See also Lim et al. (2016) for a recent attempt to measure direct and indirect incentives in hedge funds.

${ }^{4}$ In the U.K., for example, pension fund fees may be based on assets under management (AUM), on a combination of AUM and contributions, or on a combination of a fixed fee and AUM http://www.legislation.gov.uk/uksi/2015/879/regulation/5/made).

${ }_{5}$ Illig (2007) and earlier studies (e.g., Manges, 1972; Lovitch, 1975) indicate that the "hostile" attitude towards incentive fees in money management in the United States dates back to the Investment Advisers Act of 1940 and especially to a series of regulations in the 1970s which imposed restrictions on the kind of incentive fees which could be allowed (e.g., requiring a symmetry of incentives) and on the type of clients to whom money management funds with incentive fees could be offered.

${ }^{6}$ Kahan and Rock (2007) blame this fee structure for the passive attitudes of institutional investors towards monitoring management in the United States. Mahoney (2004) and Illig (2007) argue that easing regulatory restrictions on incentive pay for fund managers would benefit investors.
} 
and fund fees. This important link, however, assumes that inflows are driven by savers' correct evaluation of the relevant fund performance. We discuss this strong assumption below.

Empirically, an extensive literature on mutual funds has shown that the combination of competition and AUM-based fees can distort investment incentives. One possible reason is that fund managers focus on the kind of investment performance that would attract inflows and increase AUM. To the extent that inflows are determined by a fund's short-term past performance relative to that of its competitors (see, for example, Sirri and Tufano, 1998), the combination of AUM-based fees and competition may induce fund managers to maximize absolute short-term, rather than risk-adjusted longterm, returns and focus on relative performance. This may lead to inefficient levels of risk taking (Chevalier and Ellison, 1997 and 1999) and to "herding" (Grinblatt et al., 1995; Wermers, 1999), where most funds make similar investment decisions, thereby adversely affecting performance and possibly threatening the stability of the financial system. In the context of retirement savings, managerial focus on short-term performance could seriously jeopardize the long-term interests of savers. While performance-based fees may also introduce short-term incentives, their structure can be tailored to ensure that they provide money managers with incentives to focus on the appropriate investment horizon. Competition does not award such flexibility.

Ideally, one should study the effect of performance-based fees and competition on investment performance by comparing two otherwise identical funds that differ, for exogenous reasons, only with respect to their fee structure and competitive environment. However, as regulators worldwide are generally opposed to performance-based fees, such a research design may not be feasible with respect to pension funds. In Israel, however, a unique historical regulatory setting provides a rare opportunity to estimate the effect of incentives and competition on fund performance. A decade-long process of reform has created exogenous differences among retirement savings schemes in both their management fee structure and the intensity of the competition they face, based on the year in which a specific retirement savings scheme was established. Moreover, in many cases the same management companies run all types of savings schemes contemporaneously. This unique environment enables us to study how the fee structure 
and the intensity of competition affect the quality of management and risk taking of longterm savings schemes.

We use monthly data on asset allocations and returns for 72 long-term savings funds for the 11-year period between January 2005 and February 2016. There are three types of funds in the sample: (i) funds with performance-based fees, facing no competition; (ii) funds with AUM-based fees, facing low competitive pressure; and (iii) funds with AUM-based fees, operating in a highly competitive environment. The sample period includes the financial crisis of 2008, when funds taking higher risks would have been penalized.

Our main findings are as follows: First, funds with performance-based fees exhibit higher returns than funds with AUM-based fees. They may also exhibit higher risk, depending on the measures used, although for the most part differences in risk are not significant. Second, and perhaps more importantly, funds with performance-based fees consistently exhibit higher risk-adjusted returns, as measured by $\alpha$ (calculated using several alternative methods). The difference in (gross) $\alpha$ between funds with incentive fees and those with AUM-based fees is estimated to be about $0.85 \%$ per year. ${ }^{7}$ Third, when comparing funds with AUM-based fees facing intense competition with similar funds facing weak competition, we find that funds with AUM-based fees facing intense competition tend to under-perform funds operating with minimal competitive pressure (although the differences are smaller than in the comparisons between funds with performance-based fees and funds with AUM-based fees). Competition, however, seems to be associated with reduced fees.

These findings have several implications for the regulation of private pension funds. First, in the retirement savings industry incentives and competition do not appear to be perfect substitutes. ${ }^{8}$ The performance of the portfolio of a saver who allocated her retirement savings to funds with performance-based fees would be different from

\footnotetext{
${ }^{7}$ The relation between $\alpha$ and investment in illiquid assets is discussed below, but other than this effect, we do not attempt to attribute $\alpha$ to market timing, asset allocation, or security selection. For an attempt to do so in the context of U.S. pension funds, see Andonov et al. (2013).

${ }^{8}$ Giroud and Mueller (2011) discuss several theoretical models of the relation between incentives and competition. Although studies differ in their assumptions and results, there is considerable theoretical support for the intuitive conjecture that incentives and competition are, under certain conditions, substitutes.
} 
(superior to) that experienced by a saver whose retirement savings are managed in AUMbased retirement savings schemes. By contrast, the performance of the portfolio of a saver who allocated her retirement savings to funds with AUM-based fees operating in a competitive environment would tend to be inferior to the performance of the portfolio of a saver whose retirement savings' managers are shielded from competitive pressures.

Note that this finding is consistent with the view that competitive pressures may have different effects on specific funds depending on their relative performance, fund age, or their individual managers' career concerns, as documented in the literature and discussed in the next section. Our results suggest that, on average, the effects on specific funds may cancel out so that a competitive retirement savings sector exhibits results which are not superior to those of a retirement savings industry with weak competitive pressures.

Second, our findings cast doubt on the efficacy of the prohibition on performancebased fees in retirement savings funds. Specifically, we show that this prohibition may undermine the quality of fund management. Even though, in line with the regulatory rationale underlying the prohibition of performance-based fees, funds with such fees may be perceived according to some measures as riskier than other funds (according to most measures they are not), performance-based fees seem to raise the quality of fund management to an extent that savers in such funds consistently realize higher riskadjusted returns than investors in funds with AUM-based fees. We cannot determine whether the level of risk in the funds with performance-based fees in our sample is optimal (it may be the case that these funds take excessive risks or that other funds take too little risk); however, to the extent that the prohibition of performance-based fees reduces risk, this reduction comes at the cost of reducing the quality of investment management as well. Stated differently, it is possible that the natural tendency of regulators to try and prevent a pension savings crisis in the short run (through restrictions on the use of high-powered incentives and therefore on risk-taking) may come at a significant long-term cost for the retirees. ${ }^{9}$ Moreover, our results represent a lower bound,

\footnotetext{
${ }^{9}$ The policy implications outlined here reflect our understanding that the superior performance of funds with performance-based fees which we observe in the data is not simply due to fraud or accounting manipulations of fund performance (which would be very difficult under Israel's strict regulatory regime).
} 
as the performance-based fee structure in the funds in our sample is definitely suboptimal. Introducing a better structure would presumably amplify the results.

Finally, our analysis supports a new direction for regulating pension funds' fee structure and competition. Regulators wishing to contain risk-taking have at their disposal a variety of measures even under a regime of performance-based fees, such as quantitative limits on investments in certain asset classes and fiduciary duties. Yet, regulatory measures are unlikely to induce fund managers to "work hard" or focus on the long term so as to produce better risk-adjusted returns, and competition does not seem to perform well in this role either. These results suggest that it may be appropriate to consider amending the traditional prohibition on performance-based feeds, and to explore regulatory measures that could contain excessive risk-taking. At the same time, it may well be that regulators regard performance-based fees as detrimental to their own careers, rather than to the long-term well-being of savers, in which case a change in the current regulatory regime is unlikely.

The rest of the paper is organized as follows. The next section surveys some of the related literature. Section III describes the institutional background and the regulatory changes used in this study. The data set, empirical approach and main results are discussed in Section IV. Robustness tests appear in Section V, and Section VI concludes.

\section{Related Literature}

Economic and legal research on the provision of optimal incentives to private retirement schemes under the defined-contribution model is scant, even though the economic literature on retirement policy and the design of pension benefits (for instance, life-cycle investment strategies or retirement age) is quite extensive (e.g., Medill, 2000). Moreover, both economists and legal scholars have, for the most part, studied the U.S. retirement landscape, where savers are often responsible for making both contribution

\footnotetext{
Also important for our conclusion is the view that superior return is not simply due to "luck" or to the allocation of good investments which arrive at random to a specific type of fund. Instead, we view performance as a function of effort, skills and so forth. For a recent discussion of the use of incentives in money management, see also a Financial Times "Insight" article (July 9, 2015, pp. 38): http://www.ft.com/intl/cms/s/0/ba9207a8-248e-11e5-bd83-

71cb60e8f08c.html?siteedition=uk\#axzz3fTL1j3Xp .
} 
and investment decisions. These studies often focus on the quality of decisions made by individual savers or on the nature of the investment options that employers offer to their workers (see, for example, Ayers and Curtiss, 2015). As explained above, however, in many countries the regulatory landscape concerning pension savings differs from that of the United States (OECD, 2013). Only a few studies address the policy measures that can be used to align the interests of managers of private, defined-contribution retirement savings schemes with those of their savers: Gordon (1987) discusses the nature of the fiduciary duties imposed on pension fund managers. Antolin et al. (2009) and Davis (2002) study the regulatory use of quantitative restrictions to contain portfolio risk and align the interests of fund managers with those of savers.

By contrast, an extensive literature studies mutual funds, especially in the U.S. Although many U.S. savers use mutual funds for their retirement savings, there are important differences between mutual funds and private pension funds. ${ }^{10}$ The literature on performance-based fees and competition in mutual funds is discussed below.

Consider first performance-based fees. The results in the theoretical literature on principal-agent relationship in the context of money managers vary significantly with the model's assumptions: Das and Sundaram (2002) analyze a model in which managers with unobserved ability can choose effort levels and the risk of the managed portfolio. They then compare two forms of fees: the AUM fee and the "fulcrum" (relative to a benchmark) incentive fee that U.S. mutual funds are allowed to use (see discussion below). They show that, in many cases, an incentive fee is better for investors. In the model of Palomino and Prat (2003), a bonus for achieving returns above a certain threshold is optimal when the risk is controlled by the fund manager. This contract could induce excessive or insufficient risk relative to the first best, depending on the price of risk in terms of added return. Gil-Bazo and Ruiz-Verdú (2008) develop a model of a competitive market of equity mutual funds with unobservable managerial ability. They

\footnotetext{
${ }^{10}$ From a legal standpoint, U.S. mutual funds are organized as corporations and investors are shareholders. More importantly, as noted above, retirement savings schemes normally hold multiple asset-class portfolios and fund managers have broad discretion to make not only stock selection but also asset allocation decisions (Blake et. al., 1999). Relatedly, while a single pension fund manager may be in charge of a client's entire retirement savings, the manager of any single mutual fund is normally in charge of only a fraction of her client's assets. In addition, assets in mutual funds are tradable and therefore easy to assess and move, whereas retirement savings portfolios may include a variety of tradable and non-tradable assets.
} 
assume that some investors do not use all the available information and show that, in equilibrium, poorly performing funds may set higher fees than better performing funds. ${ }^{11}$

Empirical results vary considerably. U.S. law allows mutual funds to charge incentive fees only under the so-called fulcrum model-where fees must be based on an index, with increases in fees for superior performance matched by decreases in fees for inferior relative performance. Elton et al. (2003) find that funds with this (rarely used) fulcrum fee structure exhibit positive risk-adjusted returns - as measured by $\alpha$ - and end up costing their investors less than funds with standard AUM-based fees. They also find that funds with incentive fees assume more risk than funds with AUM-based fees, especially after periods of poor performance. In their study, however, there is no exogenous variation in fund fee structure (funds are the ones to choose their fee structure and investors may choose funds based on this fee structure). Also closely related is Massa and Patgiri (2009), who show that funds with incentive contracts (of a different type) exhibit more volatile returns and have a lower probability of survival. At the same time, they deliver higher risk-adjusted returns in comparison with other funds, and this superior performance is persistent. ${ }^{12}$ An advantage of our study in comparison with much of the above literature is the absence of sample selection issues, which often arise in settings where funds (and perhaps investors) endogenously choose their own fee structure.

We now turn to the literature on competition between fund managers with AUMbased fees. Coates and Hubbard (2007) argue that fierce competition exerts a strong disciplinary force on mutual funds, thereby reducing the need for legal intervention to prevent funds from charging excessive fees. Morley and Curtis (2010) claim that competition can substitute for both governance regulation and litigation. These studies, however, do not focus on the impact of competition on investment returns. By contrast, a

\footnotetext{
${ }^{11}$ Also related is a study by Basak et al. (2007) who examine the impact of the convex relationship of fund flows to relative performance. In the model of Li and Tiwari (2009), benchmark-linked, option-like "bonus" incentive fees can induce efficient effort exertion by portfolio managers. Theoretical work by Holmstrom (1999), not specifically in the context of money management, is also related: he shows that managerial career concerns have incentive effects, but these do not necessarily lead to efficient risk-taking decisions.

${ }^{12}$ Massa and Patgiri (2009) acknowledge the endogeneity of fee structure choice and try to address it by using a TSLS approach. Also in the same vein, Diaz-Mendoza et al. (2014) show, without controlling for sample selection, that Spanish mutual funds choosing to charge performance-based fees tend to outperform other funds.
} 
much larger body of literature finds that competition can distort incentives because AUM-based fees push mutual funds to compete on inflows, which are likely to be determined by a fund's short-term performance relative to that of competing funds. In such an environment, competition may lead to excessive risk taking (Chevalier and Ellison, 1997), and to investment decisions that are correlated across funds ("herding"), posing a risk to financial stability (Grinblatt et al, 1995; Wermers, 1999). Dass, Massa and Patgiri (2008) argue that mutual funds under the AUM-based fees tend to "herd" more than funds with incentive fees. They show that this behavior had a significant effect on fund performance during the high-tech bubble of the late 1990s.

Part of the literature on mutual fund competition (starting with Brown et al., 1996) characterizes it as a "tournament" and shows that a fund's relative position in the tournament affects its inflow and therefore its investment decisions and risk taking. In the same vein, a more recent study by Kempf and Ruenzi (2008) also uses the tournament analogy to describe competition between large U.S. mutual fund families, arguing that managers tend to adjust the risk of their funds on the basis of their relative position in the fund family and the family's competitive position. Kempf, Ruenzi and Thiele (2009) show that mutual fund managers respond to poor mid-year performance differently, depending on their employment risk and compensation package. Higher employment risk tends to reduce portfolio risk, while stronger incentives tend to increase it. ${ }^{13}$

While the present paper will not directly test for these phenomena, the problems that these studies identify in the context of mutual fund competition seem to apply - and perhaps become more severe - in the context of private pension funds that compete for savers. The view that competition disciplines money managers hinges on the premise that savers can compare the performance of various funds and use this information to choose retirement schemes that are consistent with their long-term interests. Such a choice, however, would be a particularly difficult task given the complexity of retirement savings products (for example, the degree to which different products protect against longevity risks) and their portfolio management. Savers would need to evaluate asset allocation decisions across very different asset classes, while taking into account their investment

\footnotetext{
${ }^{13}$ On employment termination risk and mutual fund management style, see Chevalier and Ellison (1999).
} 
horizons. Empirically, research has established that savers - and especially those who save for retirement - use very simple heuristics to choose money managers (e.g., Benartzi and Thaler, 2007), chase past returns (Ben Rephael et al., 2012), are strongly affected by their peers' choices (Mugerman et al., 2014), and in general make sub-optimal decisions with respect to their investment choices (Gennaioli and Shleifer, 2010). ${ }^{14}$

To summarize, the existing literature casts doubt on the extent to which competition can provide pension fund managers with optimal incentives to make portfolio investment decisions. While it does suggest that performance-based fees may increase portfolio risk, the literature portrays performance-based fees in a more positive light. Put differently, the literature casts doubt on the justification for the prevalent regulatory prohibition on the use of incentive fees in the pension sector. The evidence on the effectiveness of incentives in retirement savings schemes is, however, very limited, largely because, in most countries, regulators allow only AUM-based compensation in pensions. Consequently, the contest between the incentive-based and AUM-based fee structures in the retirement savings setting is still open. The present study attempts to address this gap.

\section{Institutional Background, Data and Empirical Approach}

Our empirical strategy relies on the fact that, in Israel, there are several types of private retirement schemes that differ, for exogenous (historical) reasons, in the use of performance-based fees and in the degree of their exposure to competition. "Old Life Insurance" (OLI) plans, a major instrument for retirement saving established in 1992, charge performance-based fees. In 2004, however, the concern of excessive risk-taking by these funds led regulators to prohibit the use of such fees. Starting in 2004, OLI plans can no longer admit new members, but due to grandfathering arrangements, they continue to accept monthly contributions from existing members and charge them performancebased fees. Also starting in 2004, the same management (insurance) companies, in

\footnotetext{
${ }^{14}$ Specifically in Israel, Porath and Steinberg (2013) and Shaton (2015) find that short-term returns affect inflows into retirement savings schemes. At the same time, Shaton (2015) shows that when savers are provided with easily accessible information on long-term returns, whereas information on short-term returns can only be indirectly inferred, the sensitivity of fund flows to short-term returns declines significantly.
} 
parallel with managing the OLI plans, began to offer a "New Life Insurance" (NLI) plan, which is a similar retirement savings scheme (with a life insurance component) except that fees are based on AUM. Savers in both NLI and OLI face significant switching costs and hence there are only weak competitive pressures: managers are not afraid of losing existing savers, but in the NLI case they do have to compete for the new ones. ${ }^{15}$

A third long-term savings scheme is the "Provident Fund" (PF), in which fees are AUM-based and members can easily withdraw their savings and switch to a different fund manager. Some provident funds are run by the same insurance companies managing the OLI and NLI plans, whereas others are owned by commercial investments houses or run by employers or labor unions. ${ }^{16}$ The different features of these three types of longterm savings schemes, and in particular, the differences in fees and in the extent of competition across the different types of retirement savings, are summarized in Table $1 .^{17}$ These exogenous differences allow us to test the following hypotheses:

\section{Hypotheses on the Effects of Fee Structure}

\footnotetext{
${ }^{15}$ The main switching cost associated with life-insurance-based retirement savings schemes (both OLI and $\mathrm{NLI}$ ) is related to changing life expectancy. When a person joins a life insurance plan, the rate at which her retirement savings will be converted to an annuity upon retirement is fixed; when a person shifts between similar schemes provided by different management companies, the new scheme will use a different conversion rate, reflecting the constantly increasing life expectancy and the fact that the individual has already lived with probability one a certain number of years since joining the original scheme, making her conditional life expectancy higher than it was initially. This longevity risk constitutes a significant switching cost which limits the extent of actual shifts across life-insurance plans. Post-2004 life insurance plans (NLI) may admit new savers, but the pool of potential new clients is mostly limited to individuals joining the labor force.

${ }^{16}$ The category "provident funds" (PF) includes two variants referred to in Hebrew as Kupot Gemel and Kranot Hishtalmut; the differences between these two are immaterial for much of the present discussion (the main difference between Kranot Hishtalmut and Kupot Gemel is that the former can be redeemed after a shorter savings period). PF differ from OLI and NLI plans in not having a life insurance policy embedded in them. Prior to 2008, it was possible to redeem certain PF savings in the form of a lump sum rather than an annuity. This has been restricted to a large extent after 2010. In addition, many PF changed owners early in our sample period following the "Bachar Committee" report which prohibited bank ownership of any money management funds. Finally, some PF are owned by employers or labor unions. These PF tend to charge lower fees than commercially-run PF. These institutional characteristics are not expected to have a major effect on the present analysis and the statistics we report below are averages for the entire PF industry.

${ }^{17}$ We exclude from the analysis another type of retirement savings provider, pension funds. Up to $30 \%$ of the portfolios of these funds consist of "designated" (heavily subsidized) risk-free government bonds, thereby making their performance and asset allocation decisions not comparable to those of the other types of retirement savings providers.
} 
The first hypothesis largely tracks the policy rationale underlying the prevailing prohibition of performance-based fees, namely, the perception that performance-based fees in retirement savings would lead to increased risk taking. Consider two retirement savings funds, operating in the same competitive environment and differing only in their fee structure: in Fund A fees are based purely on AUM, while in Fund B fees are calculated as a fraction of returns. ${ }^{18} \mathrm{We}$ conjecture, in line with commonly-observed regulatory restrictions, that Fund $\mathrm{B}$ will expose its members to a higher level of (priced) risk than Fund A. Consistent with the standard Finance theory and evidence, Fund B is expected to yield a higher return. ${ }^{19}$

Our second hypothesis, based on agency theory, is that performance-based incentive fees would be associated with higher risk-adjusted returns. This follows from the predictions in the literature that such fees attract better (and more expensive) managerial talent, and elicit higher effort by managers. To the extent that managerial effort and talent affect investment returns, funds with profit-based fees should exhibit higher risk-adjusted returns than funds with AUM-based fees, while facing the same level of competition. ${ }^{20}$ In our setting, the investment decisions of funds with different fee structures or varying degrees of competition under the same management are often made by the same individuals working for a fund management company that has multiple products. It is also possible that a fund management company may assign more able individuals to one type of funds. ${ }^{21}$

\footnotetext{
${ }^{18}$ Fees that depend on risk-adjusted returns in excess of a benchmark are theoretically superior to fees based on absolute returns. We focus on fees based on absolute returns because this is what we observe in the data.

19 The increased risk can take the form of high systemic risk $(\beta)$, or appear in other forms, such as large investments in relatively illiquid and risky "alternative assets." This issue is discussed further in Section IV.

${ }^{20}$ In formulating this hypothesis we do not take an explicit stand on whether it is possible to achieve high risk-adjusted returns by selecting securities within an asset class ("stock picking"), by allocating investment across asset classes, or through various forms of "market timing." We examine if all of these together are associated with better outcomes in funds with performance-based fees. Dyck et al. (2013) find that active management in Canadian pension funds tends to be profitable in less than fully developed emerging markets; our conjecture that active management could matter for retirement savings fund operating in Israel is consistent with this logic.

${ }^{21}$ Fang et al. (2014) show that mutual fund families allocate their most skilled managers to market segments in which managerial skill is most needed. An executive in one of the life insurance management companies in the sample has told one of the authors in private that he assigns his best talent to the old life insurance fund he manages.
} 


\section{Hypotheses on the Effects of Competition}

Predicting the effect of competition on fund performance is more complicated. Compare Fund A to Fund C: in both funds, fees are calculated as a fraction of AUM but, unlike Fund A, Fund $\mathrm{C}$ operates in a competitive environment where savers who are unhappy with the fund's performance can costlessly withdraw their savings, while savers from other funds can join if they like the fund's track record. Assuming full rationality of savers, theory suggests that competition should lead to a better outcome in Fund C, which would be induced to hire better portfolio managers who, in turn, will exert more effort. However, as discussed above, the existing literature suggests that the effect of competition on (mutual) fund performance may depend on the fund's short-run performance relative to competing funds and on the fund manager's career concerns. We sidestep these concerns in our analysis and use measures of average risk and return for the subsample of retirement savings funds facing strong competitive pressures (PF) and compare them with the average measures of risk and return for funds facing very weak competitive pressures (NLI plans). In addition, there are doubts in the literature about the ability of traditional measures of fund performance to capture fund management quality, or managerial skill, in a competitive environment (Berk and van Binsbergen, 2015). This issue is discussed in detail below, when we interpret our findings. Intuitively, however, given the preference of regulators to use competition as a mechanism to achieve desirable outcomes in the retirement savings sector, our conjecture is that a dollar of savings invested in a competitive money management segment should result in a better outcome than a dollar allocated to a retirement savings sector with little competitive pressure.

\section{Data and Results}

Data

Our sample is constructed from official data on retirement savings schemes published by the Israeli Ministry of Finance. We have data on monthly returns for the period starting in January 2005 and ending in February 2016, and on asset allocation starting in January 2008. Our sample period includes the years of the global financial crisis. 


\section{The Effect of Incentives on Risk and Return}

Table 2 presents summary statistics by fund type: average AUM, average monthly returns, cumulative ten-year returns (gross and net of fees), the standard deviation of monthly returns, and average fees.

OLI plans, which are large (in terms of assets under management) relative to other retirement savings schemes, ${ }^{22}$ exhibit higher returns than NLI plans (which, with one exception, are run by the same management companies, but have a different fee structure). The average monthly return in OLI plans is about 0.04 percentage points higher than in the NLI plans (gross of fees). Over the entire 11-year sample period, the cumulative return of OLI plans is about eight percentage points higher than the cumulative return of NLI plans (107\% vs. nearly $99 \%$ in nominal terms). ${ }^{23}$ OLI plans are, on average, slightly more expensive than NLI plans yet, even net of fees, savers in the OLI plans realized, over the entire period, returns which were five percentage points higher than those of savers in the NLI plans. All these differences are statistically significant. $^{24}$

In Table 2, risk, measured in terms of return volatility, appears to be similar in OLI and NLI plans. Another possible indication of the riskiness of OLI and NLI plans can be inferred from their performance in the face of an adverse shock experienced in financial markets in 2008 (and to a much smaller extent, in 2011). In 2008, the average monthly return of OLI plans was approximately $-1.54 \%$, roughly similar to the corresponding figure for NLI plans, $-1.47 \%$ (the figures for 2011 are also similar for the two types of plans, around $-0.33 \%$ per month, on average). According to this measure, then, there are also no substantial differences in the riskiness of OLI and NLI plans. There is, however, one dimension of potential risk where OLI plans do differ

\footnotetext{
${ }^{22}$ In the multivariate regressions that follow, we control for fund size to make sure our results are not driven by the allocation of talent to, or managerial focus on, the larger funds of each provider. "Conventional wisdom" has it that small funds can generate higher returns than large funds because of their "flexibility;" If this is the case, our tests may be biased against finding superior performance of the larger OLI plans.

${ }^{23}$ The cumulative inflation from January 2005 to December 2015 is about $23 \%$.

${ }^{24}$ To derive the statistical significance of the comparisons between OLI and NLI plans presented in Table 2 and in later tables, we conduct pairwise tests (i.e., the returns of the eight pairs of OLI and NLI plans under the same management). This approach assumes that the eight pairs are independent observations. We discuss this assumption in the robustness section below.
} 
significantly from other retirement savings schemes: Figure 1 shows that the fraction of illiquid assets (private loans and non-tradeable bonds, real estate, VC and PE investments etc.) is about twice as high in the portfolios of OLI plans than in other retirement savings schemes (about $27 \%$ of the OLI portfolios, on average, for the entire sample period vs. about $14-15 \%$ in the portfolios of NLI plans and PF; we discuss this issue in detail below) ${ }^{25}$ These differences may be, in part, due to the fact that OLI plans invest more than other retirement savings schemes in illiquid assets to take advantage of the liquidity premium, as they theoretically should. Presumably, investment in such assets is not only risky, but also requires effort and skill on behalf of fund managers. The profit-based incentives in OLI plans can explain the choice of managers in these schemes to assume the additional risk and exert the additional effort involved in investment in this asset class. This issue is examined more closely when we estimate risk-adjusted returns.

Taken together, the preliminary statistics presented in this section suggest that, in contrast with the prevailing regulatory perception, OLI plans provide higher returns in comparison with NLI plans, without necessarily bearing higher risk (except when risk is measured by the proportion of illiquid assets in the portfolio). All this is despite the fact that, from the management company's perspective, the simplest and the least costly course of action would have been to hold a single portfolio and then to allocate it proportionally to OLI and NLI plans.

\section{The Effect of Competition on Risk and Return}

Similar comparisons between NLI plans and PF allow us to evaluate the effects of competition. Recall that, in comparison with NLI plans, PF are exposed to intense competition for savers. Nevertheless, cumulative and average monthly returns (gross of fees) are nearly identical in the PF sector and in the NLI industry (Table 2). The standard deviation of monthly returns (Table 2) and the proportion of the portfolio invested in illiquid assets (Figure 1) in the two schemes are also quite similar for much of the sample period. This suggests that, on average, the expected performance of a retirement savings

\footnotetext{
${ }^{25}$ The proportion of investment in equity is also marginally higher in OLI plans. Note that, because the population of savers in the OLI plans is older than in NLI plans (as these plans were started earlier), the measures of risk used in this section may under-estimate the true tendency to assume additional risk in OLI plans.
} 
account in a competitive money management industry is unlikely to be very different from the performance of a similar account invested in a sector facing weak competitive pressures. $^{26}$

In Table 2, the only economically meaningful difference between NLI plans and $\mathrm{PF}$ is in management fees, which are substantially lower in the PF industry, where competition is intense ( $0.7 \%$ per annum, on average), than in the NLI sector, where switching costs are high and savers rarely move from one provider to another (the average fees in NLI plans are about $1.15 \%$ per year). Nevertheless, these figures are probably an over-estimate of the effect of competition on management fees for two main reasons: First, as noted above, NLI (and OLI) plans pre-commit to the rate at which savings will be converted to an annuity upon retirement and savers are therefore insured against the risk of rising life expectancy. Savers in PF are exposed to this longevity risk. ${ }^{27}$ In addition, as noted above, some of the PF are non-profit schemes operated by labor unions or employers, charging very low fees to employees in order to cover the fund's operating costs only. Hence, the differences in fees between PF and other retirement savings schemes reported in Table 2 are probably higher than the difference in fees an average investor would experience when switching to a commercially-owned PF from another retirement savings scheme; hence the actual net-of-fees performance of PF may be lower than what Table 2 might suggest.

Given that funds differ in size and their performance varies over time, Table 3 presents regression results where the dependent variables are gross monthly returns or the annual standard deviation of monthly returns, controlling for fund size as well as for management company- and period-fixed effects. OLI plans exhibit higher returns than

\footnotetext{
26 The literature discussed in Section II argues that competition does not have the same effect on all (mutual) funds. Poorly performing (laggard) funds or funds whose management team is young would be affected differently than leading funds or funds whose management team is mature. In addition, within our sample, labor union-owned PF might differ than commercially-run PF in both their performance and their fees. We do not examine these differences here and present only a comparison of the average performance of retirement savings schemes operating in a highly competitive environment (PF) vs. the average performance of NLI plans, where competitive pressures are weak.

${ }^{27}$ Industry sources estimate the cost of this insurance provision at $0.3-0.35 \%$ per annum; if this figure is true, the difference in fees shrinks dramatically.
} 
NLI plans (the omitted category) and PF. ${ }^{28}$ The difference between OLI and the NLI plans in the standard deviation of monthly returns regression is not statistically significant, indicating that funds with performance-based fees do not seem to take excessive risks. The comparison between PF and NLI plans suggests that PF exhibit lower returns (although the magnitude of this difference is smaller than the magnitude of the difference between OLI and NLI plans), as well as lower volatility. ${ }^{29}$ We conclude from the evidence presented so far that performance-based fees are associated with an increase in returns (there is less evidence on increased risk), whereas competition is associated, on average, with low returns and low risk. In addition, management fees are lower in a competitive environment (PF). We now turn to a comparison of risk-adjusted returns in the three retirement savings schemes.

\section{Risk-adjusted Returns by Fund Type}

Our primary measure of management quality (risk-adjusted returns) is $\alpha$, the excess return generated by fund managers, controlling for a set of risk factors, as is common in the literature. A recent study by Berk and van Binsbergen (2015), following earlier work by Berk and Green (2004), casts doubt on the ability of $\alpha$ to measure managerial skill in fund management; this is discussed when we interpret our results.

Unlike equity-only or bonds-only mutual funds, which have been the focus of much the existing literature, funds in our sample manage portfolios consisting of many asset classes, such as government and corporate bonds, in addition to equity. Therefore, to derive $\alpha$, we focus on a simple set of easily identified indices as commonly used proxies for risk factors. In our benchmark specification, we regress the monthly excess return (above the risk-free rate, derived from short term government bonds) of each fund

\footnotetext{
${ }^{28}$ In non-tabulated tests, we also examine a specification where we regress the (excess, above the risk-free rate) return of each of the eight OLI plans on the returns of the same management company's NLI plans. The correlation between the two portfolios is high, in the order of 0.9 , and yet in all eight regressions, there is a positive intercept suggesting that, while the two portfolios are similar, they are not identical and OLI plans exhibit higher returns. Casual examination of a few portfolios of OLI and NLI plans suggest that differences in the portfolios often emanate from differences in investment in illiquid assets and, in addition, there are also occasional differences in the stock and bond portfolios held by the plans, especially in holdings of small and foreign shares.

${ }^{29}$ One possible reason why NLI plans may do better than PF is "positive spillovers" from OLI plans. We return to this issue below.
} 
on the excess return of two equity indices, the Tel Aviv 100 Index and the MSCI World Index, as well as on the excess returns of three bond indices: inflation-indexed government bonds, non-indexed government bonds, and inflation-indexed corporate bonds. ${ }^{30}$ To address the possibility that these factors may not fully capture the funds' systemic risk, we examine several additional specifications for robustness.

In much of our empirical analysis, we divide the sample into four periods of 36 monthly observations each: January 2005 to December of 2007; January 2008 to December of 2010; from January 2011 to December 2013; and from January 2013 to December 2015. ${ }^{31}$ The average values of the parameters in the regressions in which $\alpha$ is estimated are presented in Table 4. First, notice that the average values of the $R$-squared are very high and roughly the same for all fund types, indicating that the risk control measures work well for all the retirement savings schemes in the sample. Second, the absolute magnitudes of the estimated $\alpha$ for all three categories appear to be high in comparison with the values of $\alpha$ typically reported in the literature for equity-only mutual funds, an issue we return to below. At this stage, it is important to note that the average $\alpha$ in OLI plans is substantially higher than in NLI plans. Moreover, $\alpha$ is higher in OLI plans in each of the four 36-month sub-periods, with somewhat smaller differences later in the sample period, an issue we discuss in Table 8 below. The $t$-statistics of the estimated $\alpha$ 's are also much higher for OLI plans. We interpret this as indicative evidence that OLI plans exhibit superior long-term money management skills due to the talent they employ and the incentives they provide. The effect of competition on $\alpha$ appears to be in the opposite direction from the effect of incentives: the average $\alpha$ in PF is smaller in

\footnotetext{
${ }^{30}$ The five risk factors that we use were developed by Professors Jacob Boudoukh and Zvi Wiener for the Ministry of Finance's official website to allow comparisons of long-term savings instruments. These are appropriate for the retirement savings schemes in our sample, because most of their investments are in these five asset categories. A unique feature of the Israeli capital market is that many government bonds and most corporate bonds are inflation-indexed. This is a remnant of the hyper-inflation in the 1980's.

${ }^{31}$ To make the last period equal in length to the previous three periods, we use a 36-month period in which the first 12 months (2013) overlap with the previous period's last 12 months. This is not ideal, as the two $\alpha$ 's calculated for the two periods may not be independent. To alleviate this concern, we also examine a specification where the last period is shorter, 24 months only (January 2014 to December 2015, not tabulated), another where the entire sample period is divided into four equal periods (reported in Table 6) and a third where we calculate $\alpha$ for the entire sample period (discussed in the text below). The results remain unchanged.
} 
magnitude than that of NLI plans, even though this difference is not statistically significant. $^{32}$

Next, we introduce various control variables: Table 5 presents regression results where the calculated $\alpha$ is the dependent variable and the right-hand-side variables include, in addition to fund type, fund size (the natural logarithm of assets under management at the beginning of the period for which $\alpha$ is calculated), as well as period and management company-fixed effects. Given that we calculate four periodic estimates of $\alpha$ for each fund, the standard errors are clustered at the fund level. ${ }^{33}$ Column 1 of Table 5 presents our benchmark specification and main finding: controlling for other factors, OLI plans generate an annual risk-adjusted return that is 1.3 percentage points higher than that generated by NLI plans. This difference is highly statistically significant. Figure 2 illustrates this phenomenon, depicting the difference in the risk-adjusted return for each management company that provides both products. For all eight companies, $\alpha$ is higher in the OLI plan, and the difference is highly statistically significant $(t=5.7)$. The probability that such a result would be obtained at random, under the assumption that the eight managers constitute independent observations and have the same skills and incentives, is about $0.25 \%$.

Column 1 also shows that NLI plans outperform PF on average, although the difference is smaller (and less statistically significant) than the difference between OLI and NLI plans. This confirms our preliminary conclusion that competition (to which PF are exposed) is not associated with superior performance.

Recall that OLI plans invest more in illiquid assets such as private loans, PE and $\mathrm{VC}$, or real estate. There is no readily available index to capture the returns on this asset class $;{ }^{34}$ however, we do observe the proportion of illiquid assets in the portfolios of most

\footnotetext{
${ }^{32}$ Table 4 also indicates that OLI plans have marginally higher equity $\beta$ 's than NLI plans, whose equity $\beta$ 's exceed those of PF.

${ }^{33}$ The results remain qualitatively unchanged when the standard errors are clustered at the management company level.

${ }^{34}$ This is due to the heterogeneity of this asset class (real estate, private loans, VC and PE, etc.) and the unavailability of regular, high frequency reports on the returns on such investments. Notice also that, while PF facing competition (and possible outflows) may be limited in their ability to invest in illiquid assets, OLI and NLI plans are both equally able to do so. The larger fraction of the portfolio allocated to illiquid assets in OLI plans suggests that the effort associated with this investment is worthwhile only in OLI plans
} 
funds in each month starting in 2008. Using this information, we calculate the average fraction of the portfolio invested in illiquid assets during the period in which $\alpha$ is calculated. The presumption is that, if investment in illiquid assets affects the measurement of risk-adjusted returns, it should manifest itself in funds (and periods) of higher proportions of such assets in the portfolio, assuming they all invest in similar types of alternative assets. The result, presented in Column 2 of Table 5, indicates that the coefficient on OLI plans declines by about $40 \%$ relative to its magnitude in Column 1 , but remains positive and significant. Thus, the higher $\alpha$ of OLI plans is attributable, in part though not completely, to the returns on the high proportion of illiquid assets held by OLI plans (the coefficient on illiquid assets itself is positive and significant). ${ }^{35}$ The difference between NLI and PF in Column 2 remains similar in magnitude to that of Column 1, although the level of statistical significance is slightly lower.

The findings in Table 5 cast further doubts on the desirability of the ubiquitous regulatory restrictions on the use of performance-based fees in retirement savings schemes. Again, funds with performance-based incentive fees (OLI plans) appear to outperform funds with AUM-based fees; and, the difference between AUM-based funds with weak competitive pressures (NLI plans) and AUM-based funds operating in a highly competitive environment (PF) indicates that competition is unlikely to be a close substitute to incentives.

Our interpretation of the results in Table 5 is based on differences in effort and ability between OLI plans and other retirement schemes. Can there be different explanations for the results in Table 5? There are no substantial differences in fund characteristics and clienteles that can easily account for these findings. Cross-plan subsidization and outright fraud over long time periods are unlikely, given the prevailing tight regulatory regime. Another alternative interpretation for the results in Table 5 can

where fees are profit-based. It may also suggest that illiquid assets are available in limited supply so that management companies have to allocate them to either OLI or NLI plans.

${ }^{35}$ To the extent that the value of investments in illiquid assets are updated less frequently than the value of investments in liquid asset classes, a large investment in illiquid assets may smooth returns and raise the measured $\alpha$. This effect, however, is unlikely to explain differences in risk-adjusted returns over long time periods. Note that the sample period used in the regression in Column 2 is shorter, as data on investments in illiquid assets become available only in 2008. Running the benchmark regression for this sample period without including investment in illiquid assets yields a coefficient on OLI plans of 1.06, so part of the difference between the coefficients in Column 1 and Column 2 is due to the sample period. 
perhaps be derived from Berk and van Binsbergen (BvB, 2015), who argue that $\alpha$ depends on the intensity of competition and should not be regarded as a measure of money management quality: a positive $\alpha$, in their view, would be driven to zero through competition between investors, i.e., funds grow until the (decreasing) returns to managerial skill or talent are equalized across all funds. In the BvB view, in order to evaluate fund management quality, or managerial skill, a measure of "value added," taking into account fund size should be used, rather than a measure of return like $\alpha$, which is independent of fund size.

We do not believe that this view of the world can explain our findings. First, as a group, OLI funds are not supposed to exhibit superior performance unless fees provide very strong incentives. After all, OLI managers are not able to increase the size of their funds and get higher fees due to inflows even if they exhibit superior return, which reduces their incentives to perform. Performance-based fees in OLI plans must provide a set of incentives which is much stronger than the ability to attract additional funds (in NLI plans, for example), leading to superior performance. Second, OLI and NLI plans are often run by the same individuals or investment committees, so that performance differences between them are unlikely to be determined by inherent management ability, but rather by the differences in incentives. Third, OLI plans are significantly larger than NLI plans (and PF) yet they nevertheless exhibit higher $\alpha$; thus, OLI plans would have out-performed NLI plans by a much bigger margin using the BvB "value added" measure. Would the superior $\alpha$ of OLI plans disappear in a regime of free flows in and out of these schemes? Possibly (we do not have empirical evidence on this), but, even if this were the case, it is not clear that this would be a desirable outcome, as free inflows and outflows might lower the flexibility of OLI plans, for example, with respect to investment in illiquid assets which, as we have seen, account for part of their superior performance.

The $\mathrm{BvB}$ critique of the use of $\alpha$ is perhaps more relevant to the comparison between the NLI plans and the PF industry, which differ in their competitive environment. It is interesting to note, however, that even though NLI plans and PF operate in different competitive environments, the difference between them in $\alpha$ turns out to be smaller than the incentives-induced difference between the OLI and NLI plans. In 
addition, in recent years NLI plans have been growing, yet the difference in $\alpha$ between them and PF seems to have increased, rather than declined as one would expect according to the BvB logic (see Table 8, which is discussed below). Overall, while the measured performance of PF could be affected by competition, we do not believe that the BvB critique undermines the importance of the role of incentives documented in Table $5 .^{36}$

The possible conclusion, that incentives and competition should not be viewed as perfect substitutes, could be a very troubling message for regulators around the world, who tend to rely almost exclusively on competition to bring about better incentives for the pension managers. It is important to repeat, however, that our analysis examines incentives and competition separately; we have no evidence on the equilibrium and on the retirees' welfare in an environment where funds with performance-based fees compete with AUM-based funds.

\section{Robustness Tests}

Table 6 presents a number of robustness tests. For ease of comparison, the benchmark specification of Table 5, Column 1, is reproduced in Column 1 of Table 6.

In Column 2 we use an "industry peer index" as an additional risk factor in the estimation of the risk-adjusted return, following the methodology of Hunter et al. (2014). We proceed as follows: first, we construct a "peer index," which is a simple average of the excess return of all funds in the entire sample. We then regress this "peer index" on the five risk factors (indices) used in the benchmark specification and include the residuals from this regression as a sixth risk factor in the estimation of $\alpha$ for each fund. This procedure is designed to control for possible omitted risk factors in all portfolios and to improve the precision of the estimated $\alpha$. The regression results across categories are virtually unchanged from those of the benchmark specification. Controlling for size and

\footnotetext{
${ }^{36}$ It is also possible to use $\alpha$ net of fees to measure fund performance (Table 10 below). We prefer to focus on the gross-of-fees $\alpha$ to measure of the "size of the pie" generated by fund managers, whereas the net-offees $\alpha$ distributes the returns between the management company and the savers. Net of fees $\alpha$ is nevertheless higher for OLI plans than for NLI plans, which have net-of-fees $\alpha$ of similar magnitude to those of PF. Another possible measure of fund performance is the Sharpe Ratio which may be more relevant to savers than $\alpha$; we nevertheless choose to focus on $\alpha$ because, despite the Berk and Green (2015) critique, it is commonly perceived as a proxy for the quality of fund management, our main variable of interest.
} 
management-company and period fixed effects, OLI plans have $\alpha$ which is $1.27 \%$ higher than that of NLI plans (vs. a difference of $1.31 \%$ in the benchmark specification). The difference in peer-adjusted $\alpha$ between NLI plans and PF remains the same as in the base case. Thus omitted risk factors, if they are common across the three categories of funds, do not seem to explain the differences.

In Column 3, we examine the possibility that the risk factors used in our regression estimates of $\alpha$ for each fund are correlated. We address this issue by using a specification where $\alpha$ is calculated in a regression that does not include the return on indexed government bonds (which is correlated with the returns on nominal government bonds and indexed corporate bonds). The estimated $\alpha$ 's are not different from those of the benchmark specification and the regression results remain virtually unchanged as well.

In Column 4 we examine the robustness of the results to the choice of subperiods. We divide the entire sample (consisting of 134 months, from January 2005 to February 2016) into three equal sub-periods of 45 months each (44 in the last period). The results are qualitatively unchanged. ${ }^{37}$

In Column 5 we use the $t$-statistic of the calculated base-specification $\alpha$ as the dependent variable to capture the differences in the estimation precision across funds and periods. In essence, this specification weighs observations of $\alpha$ according to their statistical significance. As shown in Table 4, the estimated $\alpha$ is more likely to be statistically significant for OLI plans than for other retirement savings schemes and the regression results indicate that OLI plans exhibit superior performance in this specification as well. The sign of the difference between the NLI and PF remains unchanged, but its magnitude and statistical significance is slightly lower than in other specifications. $^{38}$

Table 7 presents (together with the benchmark specification reproduced in Column 1), regression results for three subsamples: in Column 2, we include only

\footnotetext{
37 We also examine specifications with no management-company and no period fixed effects with clustering at the fund and at the management-company levels. The OLI coefficient is positive and highly statistically significant in all of these specifications.

${ }^{38}$ In another robustness test, not tabulated, we use preliminary calculations of a four-factor model for Israel derived by Garyn-Tal and Lauterbach (2015) and find that our results remain unchanged in this specification as well.
} 
insurance-owned retirement savings schemes (OLI and NLI plans as well as insuranceowned PF); in Column 3, only NLI and PF; and in Column 4, only NLI plans and insurance-owned PF. The general thrust of the results remains unchanged: OLI plans with profit-based fees exhibit higher $\alpha$ than NLI plans which, in turn, tend to do better than PF operating in a competitive environment. ${ }^{39}$

Table 8 presents the evolution over time of the differences between OLI and NLI plans, as well as between NLI plans and PF. When using $\alpha$ calculated for the entire period, OLI plans out-perform NLI plans and PF. Furthermore, OLI plans out-perform NLI plans in all periods. The gap between them, however, is larger in the first two subperiods than later in the sample. By contrast, the under-performance of PF relative to NLI is primarily a feature of the second half of the sample period. It therefore appears that the relative performance of NLI plans improves over time. ${ }^{40}$ One interpretation of this could be that, recently, NLI plans have begun to resemble OLI plans, with increasing investment in illiquid assets (Figure 1). As an illustration of this, one insurance company has recently announced that its OLI and NLI plans will be jointly managed and hold the same portfolio. In addition, in non-tabulated tests, we observe a (small) increase in the correlation of returns between OLI and NLI plans of the same managers in recent years. If PF have become less attractive alternatives to NLI (for example, because, starting in 2008, withdrawals from PF can only be made in the form of annuities rather than as a lump sum), then perhaps there is less "herding" (similarity in investment policies) between NLI plans and PF, and NLI plans, which may have become less concerned about capital outflows, invest more in illiquid assets. This is, of course, a mere conjecture.

\footnotetext{
${ }^{39}$ A comparison of Column 3 and Column 4 may suggest that insurance-owned PF tend to do better than other PF, perhaps because of "spillovers" from insurance-owned OLI plans (which affect the performance of NLI plans and insurance-owned PF relative to other PF). Presumably, illiquid and alternative assets are available in limited supply so that it is not possible for NLI plans and insurance-owned PF to completely mimic the portfolios of OLI plans.

${ }^{40}$ An alternative way to derive the statistics presented in Table 8 would to construct portfolios of funds of similar types and calculate, for each period, the portfolio $\alpha$. This relaxes the assumption that observations on the eight pairs of OLI and NLI are independent. Mathematically, instead of calculating $\alpha$ for each fund in each period and then calculating the average $\alpha$ by fund type, this procedure begins by averaging returns for each fund type and then deriving $\alpha$ for each portfolio of funds. The two procedures could differ if some observations are missing in some months, for example. In practice, the results are virtually identical for the two procedures and the conclusion from Table 8 hold on the basis of OLI and NLI portfolios as well.
} 
Table 9 presents regression specifications where we use only three of the four periods for which $\alpha$ is estimated in each regression. In the first period (early 2005 to the end of 2007), for example, returns may have been distorted because the volume of inflows into the newly-formed NLI plans was large relative to their AUM. This period also witnessed ownership changes in some PF, following the government-appointed Bachar Committee which forced banks to sell off bank-owned PF. The movement of savers across PF may have been different in this first period than in later periods. Consistent with Table 8, our results remain unchanged when the first period $\alpha$ is omitted from the regression, with a smaller difference between OLI and NLI plans and a more pronounced under-performance of PF relative to NLI plans. In the second period (early 2008 to the end of 2010), which includes the onset of the financial crisis, OLI plans may have had an "accounting advantage" to the extent that the valuation of the large proportion of illiquid assets in their portfolios did not adjust fully to the crisis. Yet our results remain qualitatively unchanged when the second period $\alpha$ is omitted from the regression. When the fourth period $\alpha$ is omitted, the estimated difference between OLI and NLI plans is larger than in the benchmark specification and in the other sub-periods because the difference in $\alpha$ between OLI and NLI plans is the smallest in the last sample period (see also Table 8). Differences between NLI plans and PF are insignificant in the regression where the last estimation period is omitted because NLI plans outperform PF later in the sample, whereas in the earlier periods the estimated $\alpha$ is similar, or even slightly higher, for PF.

Overall, our main findings remain unchanged and are consistent with the view that funds with performance-based fees are associated with superior risk-adjusted returns, in contrast with competition which tends to be detrimental to performance.

\section{Concluding Remarks}

Our main findings, evaluating the effectiveness of two key policy measures, the regulation of management fees and the introduction of competition among retirement savings schemes, are summarized in Table 10: Retirement savings schemes with profit based incentives (OLI plans) out-perform similar schemes with no incentives (NLI plans) by about $0.04 \%$ in terms of gross monthly returns $(0.03 \%$ of the net monthly returns) and 
by $0.07 \%$ in terms of gross monthly $\alpha(0.06 \%$ of the net monthly $\alpha)$. Gross of fees, the performance of retirement savings schemes subject to significant competitive pressure $(\mathrm{PF})$ is not very different from that of similar funds operating in an environment of limited competition (NLI plans); because competition is associated with low fees, net performance of PF is slightly better than that of NLI plans.

We believe that these findings are of relevance for the design of an efficient regulatory environment for defined contributions-type private pension funds, which play an increasingly important role in providing retirement income around the world. In many countries it is the managers of these pension fund managers - and not savers - who make both asset allocation and specific investment decisions. One implication of our results is that incentives may be more effective than competition in aligning the interests of pension fund managers with those of their clients. This is important, because misaligned incentives could not only harm future retirees, but also undermine investor protection, financial development, and even financial stability. Competition however, leads to lower fees for investors.

Another implication of our results has to do with the regulation of risk taking in retirement savings schemes. While most regulators worldwide take the view that profitbased fees are risky and should be prohibited in pension fund management, our results cast doubt on the validity of this view: funds with performance-based fees are associated with more risk-taking in comparison with AUM-based funds only if risk is measured in terms of investment in illiquid and presumably risky assets. Comparisons based on other measures of risk, such as return volatility, are not highly consistent with the regulatory view. By contrast, funds with performance-based fees are clearly associated with highquality investment management. Stated differently, even if funds with performance-based fees can be regarded as riskier than other funds, there seems to be a tradeoff whereby this higher risk is accompanied also by better investment management.

Given that it is unclear whether competition (or other regulatory mechanisms) can effectively incentivize fund managers, our analysis suggests that it may be appropriate to consider regulatory measures to directly contain risk-taking by fund managers, along with relaxation of the prohibition on performance-based fees. Policymakers have at their disposal a variety of such mechanisms they already use, including the imposition of 
fiduciary duties or quantitative limits on certain types of risky investment. Any potential changes should, of course, be considered with caution, given that our analysis cannot provide direct evidence on the equilibria which would arise in possible real-world hybrid combinations of competition and incentives. If, for example, funds with performancebased fees competed with funds with AUM-based fees, would the funds with incentives be able to attract the best managerial talent? Would the funds without incentives disappear? Our empirical setup enables us to compare only "pure" funds with incentives and no competition (OLI plans) vs. funds without any incentives and no competition (NLI plans), and funds with competition and no incentives (PF).

Why is it, then, that regulations which are possibly sub-optimal govern the pension fund industry in most countries? It may well be that the aversion of regulators to performance-based fees reflects their own risk aversion, viewing the risk-taking of fund managers as detrimental to their own careers. After all, nobody would blame past regulators for getting a pension that is lower than what it could have been. At the same time, one case of excess risk taking by a manager could unleash a tsunami of criticism and perhaps lead to a demise of a regulator. Rational regulators respond accordingly. In that context, the fact that the average risk taking of OLI funds does not seem to be higher, suggests that regulators may worry about extreme events. This effect could be magnified by an "information cascade" (Bikhchandani et al., 1998) across countries: the perceived disadvantage of profit-based incentive fees found its way into regulation in a few countries, and the rest have just copied it under the assumption that the first countries had been better informed. To the extent that this is the case, while a revision in the current regulatory regime should perhaps be considered, it seems unlikely.

\section{References}

Andonov, Aleksander, Rob Bauer and Martijn Cremers (2013), "Can Large Pension Funds Beat the Market? Asset Allocation, Market Timing, Security Selection, and the Limits of Liquidity," unpublished manuscript, University of Notre Dame.

Antolín, Pablo, Sandra Blome, David Karim, Stéphanie Payet, Gerhard Scheuenstuhl and Juan Yermo (2009), "Investment Regulations and Defined Contribution Pensions," OECD Working Papers on Insurance and Private Pensions No. 37, OECD Publishing. 
Ayers, Ian and Quinn Curtis (2015), "Beyond Diversification: The Pervasive Problem of Excessive Fees and "Dominated Funds" in 401(k) Plans," Yale Law Journal Vol. 124, pp. 1476-1552.

Basak, Suleiman, Anna Pavlova and Alexander Shapiro (2007), "Optimal Asset Allocation and Risk Shifting in Money Management," Review of Financial Studies, Vol. 20, pp. 1583-1621.

Benartzi, Shlomo and Richard Thaler. (2007). "Heuristics and Biases in Retirement Savings Behavior," Journal of Economic Perspectives, Vol. 21, pp. 81-104.

Ben Rephael, Azi, Shmuel Kandel and Avi Wohl (2012), "Measuring Investor Sentiment with Mutual Fund Flows," Journal of Financial Economics, Vol. 104, pp. 363-382.

Berk, Jonathan and Richard Green (2004), "Mutual Fund Flows and Performance in Rational Markets," Journal of Political Economy, Vol. 112, pp. 1269-1295.

Berk, Jonathan and Jules van Binsbergen (2015), "Measuring Skill in the Mutual Fund Industry," Journal of Financial Economics, Vol. 118, pp. 1-20.

Bikhchandani, Sushil, David Hirshleifer and Ivo Welch (1998). "Learning from the Behavior of Others: Conformity, Fads, and Informational Cascades," Journal of Economic Perspectives, Vol. 12, pp. 151-170.

Blake, David, Bruce Lehmann and Allan Timmermann (1999), "Asset Allocation Dynamics and Pension Fund Performance,”Journal of Business, Vol. 72, pp. 429-471.

Brown, Keith, W.V. Harlow and Laura Starks (1996), "Of Tournaments and Temptations: An Analysis of Managerial Incentives in the Mutual Fund Industry," Journal of Finance, Vol. 51, pp. 85-110.

Chevalier, Judith and Glenn Ellison (1997), "Risk Taking by Mutual Funds as a Response to Incentives,” Journal of Political Economy, Vol. 105, pp. 1167-1200.

Chevalier, Judith and Glenn Ellison (1999), "Career Concerns of Mutual Fund Managers," Quarterly Journal of Economics, Vol. 114, pp. 389-432.

Coates, John and Glenn Hubbard (2007), "Competition in the Mutual Fund Industry: Evidence and Implications for Policy," Journal of Corporation Law, Vol. 33, pp. 151222. 
Cooper, Jeremy (2010), “Super for Members: A New Paradigm for Australia's Retirement Income System," Rotman International Journal of Pension Management, Vol. 3, pp. 8-15.

Das, Sanjiv and Rangarajan Sundaram (2002), "Fee Speech: Signaling, Risk-Sharing and the Impact of Fee Structures on Investor Welfare," Review of Financial Studies, Vol. 15, pp. 1465-1497.

Dass, Nishant, Massimo Massa and Rajdeep Patgiri (2008), "Mutual Funds and Bubbles: The Surprising Role of Contractual Incentives," Review of Financial Studies, Vol. 21, pp. 51-99.

Davis, Philip (2002), "Prudent Person Rules or Quantitative restrictions? The Regulation of Long-term Institutional Investors` Portfolios," Journal of Pension Economics and Finance, Vol. 1, pp 157-191.

Diaz-Mendoza, Ana, German Lopez-Espinosa and Miguel Martınez (2014) "The Efficiency of Performance-Based Fee Funds," European Financial Management, Vol. 20, pp. 825-855.

Dyck, Alexander, Karl Lins and Lukasz Pomorski (2013), "Does Active Management Pay? New International Evidence," Review of Asset Pricing Studies, Vol. 3, pp. 200-228.

Elton, Edwin, Martin Gruber and Christopher Blake (2003), "Incentive Fees and Mutual Funds," Journal of Finance, Vol. 58, pp. 779-804.

Fang, Jieyan, Alexander Kempf and Monika Trapp (2014), "Fund Manager Allocation," Journal of Financial Economics, Vol. 111, pp. 661-674.

Fisch, Jill (2010), "Rethinking the Regulation of Securities Intermediaries," University of Pennsylvania Law Review, Vol. 158, pp. 1961-2041.

Garyn-Tal, Sharon and Beni Lauterbach (2015), "The Formulation of the Four Factor Model when a Considerable Proportion of Firms is Dual-Listed," Emerging Markets Review, Vol. 24, pp. 1-12.

Gennaioli, Nicola and Andrei Shleifer (2010), "What Comes to Mind," Quarterly Journal of Economics, Vol. 125, pp. 1399-1433.

Gil-Bazo, Javier and Pablo Ruiz-Verdú (2008), "When Cheaper is Better: Fee Determination in the Market for Equity Mutual Funds," Journal of Economic Behavior and Organizations, Vol.67, pp. 871-885. 
Giroud, Xavier and Holger Mueller (2011), "Corporate Governance, Product Market Competition, and Equity Prices," Journal of Finance, Vol. 66, pp. 563-600.

Gompers, Paul and Josh Lerner (1999), "An Analysis of Compensation in the U.S. Venture Capital Partnership," Journal of Financial Economics Vol. 51, pp. 3-44.

Gordon, Jeffrey (1987), "The Puzzling Persistence of the Constrained Prudent Man Rule," New York University Law Review, Vol. 62, pp. 52-115.

Grinblatt, Mark, Sheridan Titman and Russ Wermers (1995), "Momentum Investment Strategies, Portfolio Performance, and Herding: A Study of Mutual Fund Behavior," American Economic Review, Vol. 85, pp. 1088-1105.

Holmstrom, Bengt (1999), "Managerial Incentive Problems: A Dynamic Perspective," Review of Economic Studies, Vol. 66, pp. 169-182.

Hunter, David, Eugene Kandel, Shmuel Kandel and Russ Wermers (2014), “Endogenous Benchmarks," Journal of Financial Economics, Vol. 112, pp. 1-29.

Illig, Robert (2007), "What Hedge Funds Can Teach Corporate America: A Roadmap for Achieving Institutional Investor Oversight," American University Law Review, Vol. 57, pp. 225-339.

Kahan, Marcel and Edward Rock (2007), "Hedge Funds in Corporate Governance and Corporate Control," University of Pennsylvania Law Review, Vol. 155, pp. 1021-1093.

Kandel, Eugene, Dima Leshchinskii and Harry Yuklea (2011), "VC Funds: Aging Brings Myopia," Journal of Financial and Quantitative Analysis, Vol. 46, pp. 431-457.

Kempf, Alexander and Stefan Ruenzi (2008), “Tournaments in Mutual-Fund Families," Review of Financial Studies, Vol. 21, pp. 1013-1036.

Kempf, Alexander, Stefan Ruenzi and Tania Thiele (2009), "Employment Risk, Compensation Incentives, and Managerial Risk Taking: Evidence from the Mutual Fund Industry," Journal of Financial Economics, Vol. 92, pp. 92-108.

Li, Wei and Ashish Tiwari (2009), "Incentive Contracts in Delegated Portfolio Management," Review of Financial Studies, Vol. 22, pp. 4681-4714.

Lim. Jongha, Berk Sensoy and Michael Weisbach (2016), "Indirect Incentives of Hedge Fund Managers," Journal of Finance, Vol. 71, pp. 871-918.

Lovitch, Fred (1975), “The Investment Advisers Act of 1940-Who Is an Investment Adviser?" University of Kansas Law Review, Vol. 24, pp. 67-104. 
Ma, Linlin, Yuehua Tang and Juan-Pedro Gómez (2015), "Portfolio Manager Compensation in the U.S. Mutual Fund Industry," unpublished manuscript, IE Business School.

Mahoney, Paul (2004), "Manager-Investor Conflicts in Mutual Funds," Journal of Economic Perspectives, Vol. 18, pp. 161-182.

Manges, Gerard (1972), “The Investment Company Amendments Act of 1970-An Analysis and Appraisal after Two Years," Boston College Industrial and Commercial Law Review, Vol. 14, pp. 387-436.

Martin, Roger (2014), "Why Monopolistic Pension Funds Undermine Capitalism," Harvard Business Review Online, October 6, 2014.

Massa, Massimo and Radjeep Patgiri (2009), "Incentives and Mutual Fund Performance: Higher Performance or Just Higher Risk Taking?" Review of Financial Studies, Vol. 22, pp. 1777-1815.

Medill, Colleen (2000), "The Individual Responsibility Model of Retirement Plans Today: Conforming ERISA Policy to Reality," Emory Law Journal, Vol. 49, pp. 1 - 53. Metrick, Andrew and Ayako Yasuda (2010), "The Economics of Private Equity Funds," Review of Financial Studies, Vol. 23, pp. 2303-2341.

Moreolo, Carlo (2015), "Italian Regulator Questions Merit of Pension Fund Competition Bill," Investments \& Pension Europe, July 3, 2015.

Morley, John and Quinn Curtis (2010), “Taking Exit Rights Seriously: Why Governance and Fee Litigation Don't Work in Mutual Funds," Yale Law Journal, Vol. 120, pp. 84142.

Mugerman, Yevgeny, Orly Sade and Moshe Shayo (2014), "Long Term Savings Decisions: Financial Reform, Peer Effects and Ethnicity," Journal of Economic Behavior \& Organization, Vol. 106, pp. 235-253.

OECD (2011), Pensions at a Glance: Retirement-income Systems in OECD and G20 Countries (Paris, OECD Publishing).

OECD (2013), Pensions at a Glance: OECD and G20 Indicators (Paris, OECD Publishing).

OECD (2014), Pension Market Focus No. 11 (Paris, OECD Publishing). 
Palomino, Frederic and Andrea Prat (2003), "Risk Taking and Optimal Contracts for Money Managers," RAND Journal of Economics, Vol. 34, pp. 113-137.

Porath. Yehuda and Nadav Steinberg (2013), "Chasing Their Tails: Inflow Momentum and Yield Chasing among Provident Fund Investors in Israel," Israel Economic Review Vol. 10, pp. 71-106.

Shaton, Maya (2015), "The Display of Information and Household Investment Behavior," unpublished manuscript, the University of Chicago.

Sirri, Erik and Peter Tufano (1998), "Costly Search and Mutual Fund Flows," Journal of Finance, Vol. 53, pp. 1589-1622.

Wermers, Russ (1999), "Mutual Fund Herding and the Impact on Stock Prices," Journal of Finance, Vol. 54, pp. 581-622. 
Table 1: Types of Retirement Savings Schemes in the Sample

Competition/Fee

Structure
AUM

Incentive Fees

\section{Weak Competition}

N/A

$\mathrm{NLI}^{(\mathrm{ii})}$

$\mathrm{N}=9$
$\mathrm{OLI}^{(\mathrm{i})}$

$\mathrm{N}=8$

N/A

\section{Strong Competition}

\section{Provident Funds ${ }^{(i i i)}$}

$\mathrm{N}=55$

(i) Old Life Insurance (OLI) Plans (established before 2004): Life-insurance policies with a very substantial savings component. Fees are based on a combination of a relatively small AUM-based fee (up to $0.6 \%$ ) and a large performance-based fee (up to $15 \%$ of inflation-adjusted returns). A high-watermark provision ensures that the fund manager collects such fees only after any losses from previous years have been recouped; no fees are charged on deposits. These funds are closed to new members; old members can leave without a tax penalty, but lose important benefits when doing so. Old members can, however, discontinue deposits and retain some of their benefits. In January 2013 two insurance companies merged, leaving a sample of seven OLI plans in the years 2013-2016.

(ii) New Life Insurance (NLI) Plans (established in 2004 or later): These are generally similar the OLI plans, except that fees are based primarily on AUM (and on monthly deposits). Unlike the OLI plans, the NLI ones are open to new members, but savers face substantial switching costs and are unlikely to leave or switch plans. In addition to the eight insurance companies providing OLI plans, the sample includes one additional insurance company offering only a NLI plan. The same merger mentioned in (i) reduced the sample of NLI plans to eight in the years 2013-2016.

(iii) Provident (including shorter term) Funds (PF): A long-term saving scheme with roughly the same tax benefits as life insurance plans, but without insurance coverage. Fees on these products are based on AUM and the environment they operate in today is highly competitive and without switching costs. Tax regulations allow most savers in PF to withdraw their savings after 15 (and sometimes fewer) years without any tax penalty, although such a withdrawal involves the loss of tax benefits on future returns. PF are closest to U.S. mutual funds in the environment they operate in. Our sample includes only PF whose assets under management, as of 2013, exceeded NIS 500 million (about $\$ 125$ million). To the extent that there are some funds which used to be above the threshold and no longer satisfy the size criterion in 2013, the performance of the PF industry that we measure may be an upper bound on the sector's actual performance. The actual number of funds varies slightly in some months. 
Table 2: Sample Statistics by Fund Type

\begin{tabular}{|c|c|c|c|c|c|}
\hline & $\begin{array}{c}\text { Average Fund AUM } \\
\text { (billions NIS, as of 12/2013) }\end{array}$ & $\begin{array}{l}\text { Average Gross } \\
\text { Monthly Return } \\
\text { (1/2005-2/2016) }\end{array}$ & $\begin{array}{c}\text { Cumulative Gross } \\
\text { [Net] Returns } \\
(\mathbf{1} / \mathbf{2 0 0 5 - 2 / 2 0 1 6 )}\end{array}$ & $\begin{array}{l}\text { Average } \\
\text { Annual } \\
\text { STD of } \\
\text { Monthly } \\
\text { Returns }\end{array}$ & $\begin{array}{c}\text { Average } \\
\text { Annual Fees }\end{array}$ \\
\hline Old Life Insurance & $18.5^{*}$ & $0.57 \% *$ & $107.07 \% *$ & $1.56 \%$ & $1.28 \% *$ \\
\hline Plans & $(6.5)$ & $(0.06)$ & {$[79.85 \%]$} & $(0.06)$ & $(0.07)$ \\
\hline New Life Insurance & 4.2 & $0.53 \%$ & $98.67 \%$ & $1.56 \%$ & $1.15 \%$ \\
\hline Plans & (1.6) & $(0.05)$ & {$[74.86 \%]$} & $(0.06)$ & $(0.02)$ \\
\hline Provident Funds & $\begin{array}{c}2.8 \\
(0.5)\end{array}$ & $\begin{array}{l}0.52 \% \\
(0.02)\end{array}$ & $\begin{array}{c}96.71 \% \\
{[81.82 \%]}\end{array}$ & $\begin{array}{l}1.51 \% \\
(0.03)\end{array}$ & $\begin{array}{l}0.71 \% \\
(0.02)\end{array}$ \\
\hline
\end{tabular}

Notes: Fund size in US dollar terms is about $1 / 4$ of the reported size in NIS terms. Monthly and cumulative returns are gross returns in nominal terms. The standard deviation of monthly returns is calculated annually and then averaged across years and fund types. Fees refer to total fund fees charged (excluding life insurance fees). OLI and NLI funds provide "longevity insurance" that does not exist in the PF, thus the differences in the fees and net returns may be overstated (see footnote 27). Standard errors (standard deviations divided by the square root of the number of observations) appear in parentheses except for cumulative returns where returns net of fees appear in square brackets. * denotes cases where differences between OLI and NLI plans are statistically significant at conventional levels in pairwise (within fund-manager) $t$-tests. None of the differences between all NLI plans and all PF (in non-paired tests) is statistically significant, except the difference in fees. 
Table 3: Comparison of Risk and Return of Retirement Savings Schemes 1/2005-2/2016

\begin{tabular}{|c|c|c|}
\hline & Monthly Return & $\begin{array}{l}\text { Standard Deviation } \\
\text { of Monthly Returns }\end{array}$ \\
\hline & (1) & (2) \\
\hline Old Life Insurance Plans & $\begin{array}{l}0.08 * * * \\
(0.02)\end{array}$ & $\begin{array}{c}0.03 \\
(0.05)\end{array}$ \\
\hline Provident Funds Scheme & $\begin{array}{l}-0.03 * * \\
(0.01)\end{array}$ & $\begin{array}{l}-0.07 * \\
(0.04)\end{array}$ \\
\hline Size $(\log$ AUM) & $\begin{array}{l}-0.03 * * \\
(0.01)\end{array}$ & $\begin{array}{l}-0.02 \\
(0.02)\end{array}$ \\
\hline Observations & 8,623 & 711 \\
\hline$R^{2}$ & .25 & .77 \\
\hline Year Fixed Effects & Yes & Yes \\
\hline $\begin{array}{l}\text { Management Company } \\
\text { Fixed Effects }\end{array}$ & Yes & Yes \\
\hline \multicolumn{3}{|c|}{$\begin{array}{l}\text { Notes: OLS regressions; robust standard errors, clustered at the fund level }(72 \\
\text { funds) are in parentheses. The dependent variables are, in Column } 1 \text {, monthly } \\
\text { gross return }(\%) \text { and, in Column } 2 \text {, the annual standard deviation of monthly } \\
\text { returns }(\%) . * *=\text { Significant at the } 1 \text {-percent level; } * *=\text { Significant at the } 5 \text {-percent } \\
\text { level; } *=\text { Significant at the } 10 \text {-percent level. }\end{array}$} \\
\hline
\end{tabular}


Table 4: Comparison of Individual Fund Regression Results by Fund Type

\begin{tabular}{|c|c|c|c|c|c|c|}
\hline & $\begin{array}{l}\boldsymbol{R}^{2} \\
(1) \\
\end{array}$ & $\begin{array}{c}\boldsymbol{\alpha} \\
(2) \\
\end{array}$ & $\begin{array}{c}\text { t-stat of } \boldsymbol{\alpha} \\
(3) \\
\end{array}$ & $\begin{array}{c}\boldsymbol{\beta} \\
\text { Tel Aviv } 100 \\
(4) \\
\end{array}$ & $\begin{array}{c}\boldsymbol{\beta} \\
\text { MSCI World } \\
(5) \\
\end{array}$ & $\begin{array}{c}\boldsymbol{\beta} \\
\text { Corporate } \\
\text { Bonds } \\
(6) \\
\end{array}$ \\
\hline Old Life Insurance Plans & $\begin{array}{c}0.91 \\
(0.01)\end{array}$ & $\begin{array}{c}2.53^{*} \\
(0.19)\end{array}$ & $\begin{array}{l}2.23 * \\
(0.18)\end{array}$ & $\begin{array}{c}0.22 \\
(0.01)\end{array}$ & $\begin{array}{c}0.19 \\
(0.01)\end{array}$ & $\begin{array}{c}0.39 \\
(0.04)\end{array}$ \\
\hline New Life Insurance Plans & $\begin{array}{c}0.92 \\
(0.01)\end{array}$ & $\begin{array}{c}1.66 \\
(0.23)\end{array}$ & $\begin{array}{c}1.57 \\
(0.21)\end{array}$ & $\begin{array}{c}0.22 \\
(0.01)\end{array}$ & $\begin{array}{c}0.16 \\
(0.01)\end{array}$ & $\begin{array}{c}0.36 \\
(0.04)\end{array}$ \\
\hline Provident Funds & $\begin{array}{c}0.93 \\
(0.01)\end{array}$ & $\begin{array}{c}1.42 \\
(0.10)\end{array}$ & $\begin{array}{c}1.42 \\
(0.075)\end{array}$ & $\begin{array}{c}0.20 \dagger \\
(0.003)\end{array}$ & $\begin{array}{c}0.125 \dagger \\
(0.005)\end{array}$ & $\begin{array}{c}0.39 \\
(0.02)\end{array}$ \\
\hline
\end{tabular}

Notes: The table reports factor loadings from fund-specific regressions where the dependent variable is the monthly excess return (and the risk free rate is derived from yields on short-term government bonds) on a number of indices (proxies) for risk factors. $\alpha$ is expressed in percent, in annual terms. 36month periods are used in all regressions (2005-2007; 2008-2010; 2011-2013; 2013-2015), with 1/2005 as the starting month. All means are unweighted; standard errors (the standard deviation of the variable, divided by the square root of the number of observations) are in parentheses. $*$ denotes cases where differences between OLI and NLI plans are statistically significant at conventional levels in pairwise (within fund-managers) $t$-tests. $\uparrow$ denotes cases where differences between NLI plans and PF are statistically significant at conventional levels (in non-paired tests). 
Table 5 - The Effect of Incentive Fees and Competition on Risk-Adjusted Return

\begin{tabular}{lcc}
\hline \hline & \multicolumn{2}{c}{ Whole Sample } \\
\cline { 2 - 3 } Old Life Insurance Plans & $(1)$ & $(2)$ \\
Provident Funds & $1.31^{* * *}$ & $0.77^{* *}$ \\
& $(0.26)$ & $(0.32)$ \\
Percentage in Illiquid Assets & $-0.32 *$ & -0.40 \\
& $(0.17)$ & $(0.26)$ \\
Size (log AUM) & & $4.75^{* * *}$ \\
Observations & $-0.22 * * *$ & $(1.67)$ \\
$\boldsymbol{R}^{2}$ & $(0.08)$ & $-0.35^{* *}$ \\
\hline Period Fixed Effects & 224 & $16.16)$ \\
Management Company Fixed & .46 & .47 \\
Effects & Yes & Yes \\
\end{tabular}

Notes: OLS regressions; robust standard errors, clustered at the fund level (Column $1-72$ funds, Column 2 - 64 funds) are in parentheses. The dependent variable is the calculated $\alpha$ for four 36-month periods, expressed in percent in annual terms. Column 1 presents our main specification, and includes all funds in the sample; Column 2 adds to the regression the average percentage of the portfolio invested in illiquid assets during the estimation period as a control variable. $* * *=$ Significant at the 1 -percent level; ** $=$ Significant at the 5 -percent level; $*=$ Significant at the 10 percent level. 
Table 6 - Alternative Specifications

\begin{tabular}{|c|c|c|c|c|c|}
\hline & Base Spec & Peers & Factor & Period & t-stat \\
\hline & (1) & (2) & (3) & (4) & (5) \\
\hline Old Life Insurance Plans & $\begin{array}{l}1.31 * * * \\
(0.26)\end{array}$ & $\begin{array}{l}1.27 * * * \\
(0.26)\end{array}$ & $\begin{array}{l}1.29 * * * \\
(0.26)\end{array}$ & $\begin{array}{l}0.957 * * * \\
(0.238)\end{array}$ & $\begin{array}{l}0.910 * * * \\
(0.184)\end{array}$ \\
\hline Provident Funds Scheme & $\begin{array}{l}-0.32 * \\
(0.17)\end{array}$ & $\begin{array}{l}-0.33 * \\
(0.17)\end{array}$ & $\begin{array}{l}-0.33 * \\
(0.18)\end{array}$ & $\begin{array}{l}-0.372 * * \\
(0.168)\end{array}$ & $\begin{array}{l}-0.205 \\
(0.184)\end{array}$ \\
\hline Size $(\log$ AUM) & $\begin{array}{l}-0.22 * * * \\
(0.08)\end{array}$ & $\begin{array}{l}-0.22 * * * \\
(0.08)\end{array}$ & $\begin{array}{l}-0.22 * * * \\
(0.08)\end{array}$ & $\begin{array}{l}-0.09 \\
(0.08)\end{array}$ & $\begin{array}{l}-0.13 * * \\
(0.05)\end{array}$ \\
\hline $\begin{array}{l}\text { Observations } \\
R^{2}\end{array}$ & $\begin{array}{r}224 \\
.46\end{array}$ & $\begin{array}{r}224 \\
.46\end{array}$ & $\begin{array}{r}224 \\
.45\end{array}$ & $\begin{array}{r}162 \\
.63\end{array}$ & $\begin{array}{r}224 \\
.38\end{array}$ \\
\hline $\begin{array}{l}\text { Period Fixed Effects } \\
\text { Manager Fixed Effects }\end{array}$ & $\begin{array}{l}\text { Yes } \\
\text { Yes } \\
\end{array}$ & $\begin{array}{l}\text { Yes } \\
\text { Yes }\end{array}$ & $\begin{array}{l}\text { Yes } \\
\text { Yes }\end{array}$ & $\begin{array}{l}\text { Yes } \\
\text { Yes }\end{array}$ & $\begin{array}{l}\text { Yes } \\
\text { Yes }\end{array}$ \\
\hline \multicolumn{6}{|c|}{$\begin{array}{l}\text { Notes: OLS regressions; robust standard errors, clustered at the fund level ( } 72 \text { funds in Columns } 1-3 \text { and Column } 5 \text {; } \\
\text { and } 71 \text { funds in Column } 4 \text { ) are in parentheses. In Columns } 1-3 \text { the dependent variable is calculated } \alpha \text { for four } 36- \\
\text { month periods, expressed in percent in annual terms. Column } 1 \text { reproduces the benchmark specification from Table } \\
5 \text {, Column } 1 \text {. In Column } 2 \text { the dependent variable is the peer-adjusted } \alpha \text { where an additional risk factor is added } \\
\text { based on the performance of all funds in the industry (see Hunter et al., } 2014 \text { and explanation in the text). In Column } \\
3 \text { the dependent variable is } \alpha \text { which is derived from a specification without the indexed government bonds factor. In } \\
\text { Column } 4 \text { we estimate } \alpha \text { using three non-overlapping periods (consisting of } 45 \text { months in the first two periods and } \\
44 \text { months in the third). In Column } 5 \text { the dependent variable is the } t \text {-statistic of the estimated } \alpha \text { in the base } \\
\text { specification. } * * *=\text { Significant at the } 1 \text { percent level. } * *=\text { Significant at the } 5 \text { percent level }{ }^{*}=\text { Significant at the } 10 \\
\text { percent level }\end{array}$} \\
\hline
\end{tabular}


Table 7 - Restricted Samples

\begin{tabular}{cccc} 
Base Spec & $\begin{array}{c}\text { Insurance- } \\
\text { only }\end{array}$ & $\begin{array}{c}\text { Provident } \\
\text { \& New }\end{array}$ & $\begin{array}{c}\text { Provident } \\
\text { (Insurance- } \\
\text { owned) } \\
\text { \& New }\end{array}$ \\
\cline { 1 - 4 }$(1)$ & $(2)$ & $(3)$ & $(4)$ \\
$1.31 * * *$ & $0.75 * * *$ & & \\
$(0.26)$ & $(0.26)$ & & \\
$-0.32 *$ & $-0.30 * *$ & $-0.33 *$ & $-0.26 * *$ \\
$(0.17)$ & $(0.13)$ & $(0.17)$ & $(0.11)$ \\
$-0.22 * * *$ & 0.00 & $-0.24 * * *$ & -0.06 \\
$(0.08)$ & $(0.09)$ & $(0.08)$ & $(0.10)$ \\
224 & 94 & 194 & 64 \\
.46 & .31 & .45 & .26 \\
& & & \\
\hline Yes & Yes & Yes & Yes \\
Yes & Yes & Yes & Yes \\
\hline
\end{tabular}

$\begin{array}{llllc}\text { Period Fixed Effects } & \text { Yes } & \text { Yes } & \text { Yes } & \text { Yes } \\ \text { Manager Fixed Effects } & \text { Ytes: OLS regressions; robust standard errors, clustered at the fund level (Column } 1-72 \text { funds, }\end{array}$ Column $2-27$ funds, Column 3-64 funds, Column $4-19$ funds) are in parentheses. The dependent variable is the calculated $\alpha$ for four 36-month periods, expressed in percent in annual terms. Column 1 reproduces the benchmark specification from Table 5, Column 1. In Column 2 the sample is restricted to insurance-owned OLI and NLI plans and insurance-owned PF; in Column 3, to NLI plans and PF only; and in Column 4, to NLI plans and insurance company-owned PF. $* * *=$ Significant at the 1 -percent level; $* *=$ Significant at the 5 -percent level; $*=$ Significant at the 10 percent level. 
Table 8: Estimated $\alpha$ by Fund Type and Period

\begin{tabular}{|c|c|c|c|c|c|}
\hline & $\begin{array}{l}\text { Entire } \\
\text { Period }\end{array}$ & $\begin{array}{c}\text { 1/2005- } \\
12 / 2007\end{array}$ & $\begin{array}{l}1 / 2008- \\
12 / 2010\end{array}$ & $\begin{array}{l}\text { 1/2011- } \\
12 / 2013\end{array}$ & $\begin{array}{l}1 / 2013- \\
12 / 2015\end{array}$ \\
\hline & (1) & (2) & (3) & (4) & (5) \\
\hline Old Life & $2.26 \% *$ & $2.20 \% *$ & $3.05 \% *$ & $2.27 \% *$ & $2.56 \% *$ \\
\hline Insurance Plans & $(0.22)$ & $(0.19)$ & $(0.57)$ & $(0.30)$ & $(0.34)$ \\
\hline New Life & $1.57 \%$ & $1.31 \%$ & $1.36 \%$ & $1.81 \%$ & $2.19 \%$ \\
\hline Insurance Plans & $(0.20)$ & $(0.35)$ & $(0.74)$ & $(0.21)$ & $(0.20)$ \\
\hline \multirow{2}{*}{ Provident Funds } & $1.25 \%$ & $1.58 \%$ & $1.47 \%$ & $1.39 \%$ & $1.08 \%{ }^{\dagger}$ \\
\hline & $(0.15)$ & $(0.25)$ & $(0.22)$ & $(0.12)$ & $(0.11)$ \\
\hline \multicolumn{6}{|c|}{$\begin{array}{l}\text { Notes: The table reports } \alpha \text { estimated for sub-periods, expressed in percent, in annual terms. Column } 1 \\
\text { presents the calculated } \alpha \text { for the entire sample period (134 months). Column } 2 \text { presents the calculated } \alpha \text { for } \\
\text { the first period }(1 / 2005-12 / 2007) \text {; Column } 3 \text { the calculated } \alpha \text { for the second period }(1 / 2008-12 / 2010) \text {; } \\
\text { Column } 4 \text { the calculated } \alpha \text { for the third period }(1 / 2011-12 / 2013) \text {; and Column } 5 \text { presents the calculated } \alpha \\
\text { for the last period }(1 / 2013-12 / 2015) \text {. All means are unweighted; standard errors (the standard deviation of } \\
\text { the variable, divided by the square root of the number of observations) are in parentheses. * denotes cases } \\
\text { where differences between OLI and NLI plans are statistically significant in pairwise (within fund- } \\
\text { managers) } t \text {-tests. } \dagger \text { denotes cases where differences between NLI plans and PF are statistically significant } \\
\text { at conventional levels (in non-paired tests). }\end{array}$} \\
\hline
\end{tabular}


Table 9 - Regressions for Sub-Periods

$\begin{array}{llll}\text { Base Spec } & 1^{\text {st }}, 2^{\text {nd }} \text { and } & 1^{\text {st }}, 3^{\text {d }} \text { and } 4^{\text {th }} & 2^{\text {nd }}, 3^{\text {d }} \text { and } \\ 3^{\text {d }} \text { Periods } & \text { Periods } & 4^{\text {th }} \text { Periods }\end{array}$

(1) (2) (3)

\begin{tabular}{llccc} 
Old Life Insurance Plans & $1.31 * * *$ & $1.58^{* * *}$ & $1.09 * * *$ & $1.06^{* * *}$ \\
& $(0.26)$ & $(0.28)$ & $(0.35)$ & $(0.30)$ \\
Provident Funds Scheme & $-0.32 *$ & -0.08 & $-0.45^{* * *}$ & $-0.50^{* *}$ \\
& $(0.17)$ & $(0.19)$ & $(0.16)$ & $(0.23)$ \\
Size (log AUM) & $-0.22 * * *$ & $-0.26^{* * *}$ & -0.19 & -0.22 \\
& $(0.08)$ & $(0.08)$ & $(0.12)$ & $(0.133)$ \\
Observations & 224 & 187 & 154 & 168 \\
$\boldsymbol{R}^{2}$ & .46 & .52 & .61 & .44 \\
\hline Period Fixed Effects & Yes & Yes & Yes & Yes \\
Manager Fixed Effects & Yes & Yes & Yes & Yes \\
\hline
\end{tabular}

Notes: OLS regressions; robust standard errors, clustered at the fund level (around 70 funds in each regression) are in parentheses. The dependent variable is the calculated $\alpha$ for 36-month periods, expressed in percent in annual terms. Column 1 replicates the benchmark specification from Table 5, Column 1 . In Column 2 we use the calculated $\alpha$ for the first three periods only $(1 / 2005-12 / 2007,1 / 2008-12 / 2010$, and 1/2011-12/2013) and omit the fourth period; in Column 3 we use the calculated $\alpha$ for the first and last two periods (1/2005-12/2007, 1/2011-12/2013, and 1/2013-12/2015) and omit the second period; in Column 4 we use the calculated $\alpha$ for the last three periods $(1 / 2008-12 / 2010,1 / 2011-12 / 2013$, and 1/2013-12/2015) and omit the first period. $* * *=$ Significant at the 1 -percent level; $* *=$ Significant at the 5 -percent level; $*=$ Significant at the 10 percent level. 
Table 10: Summary of the Main Results

\section{Monthly Gross \\ Raw Return}

(1)

$0.57 \% *$

(0.06)

$0.53 \%$

$(0.05)$

$0.52 \%$

$(0.02)$

\section{Monthly Gross}

Alpha

(2)

$0.21 \% *$

$(0.02)$

$0.14 \%$

$(0.02)$

$0.12 \%$

$(0.01)$
Monthly Net

Raw Return

(3)

$0.46 \%$ *

(0.06)

$0.43 \%$

(0.05)

$0.46 \%$

(0.02)

\section{Monthly Net}

Alpha

(4)

Provident Funds

$(0.02) \quad(0.02) \quad(0.01)$

Notes: Column 1 reproduces figures presented in Table 2. Figures in Column 2 are differences across fund types in the average $\alpha$ (from Table 4), expressed in monthly terms. Figures in Column 3 are the differences in gross raw monthly returns from Table 2 (reproduced here in Column 1) minus the differences in fees (expressed in monthly terms), also from Table 2 . Column 4 presents differences in net $\alpha$ using the gross monthly $\alpha$ from Column 2 and the fees (expressed in monthly terms), from Table 2. 
Figure 1: Percent of Assets Invested in Illiquid Assets

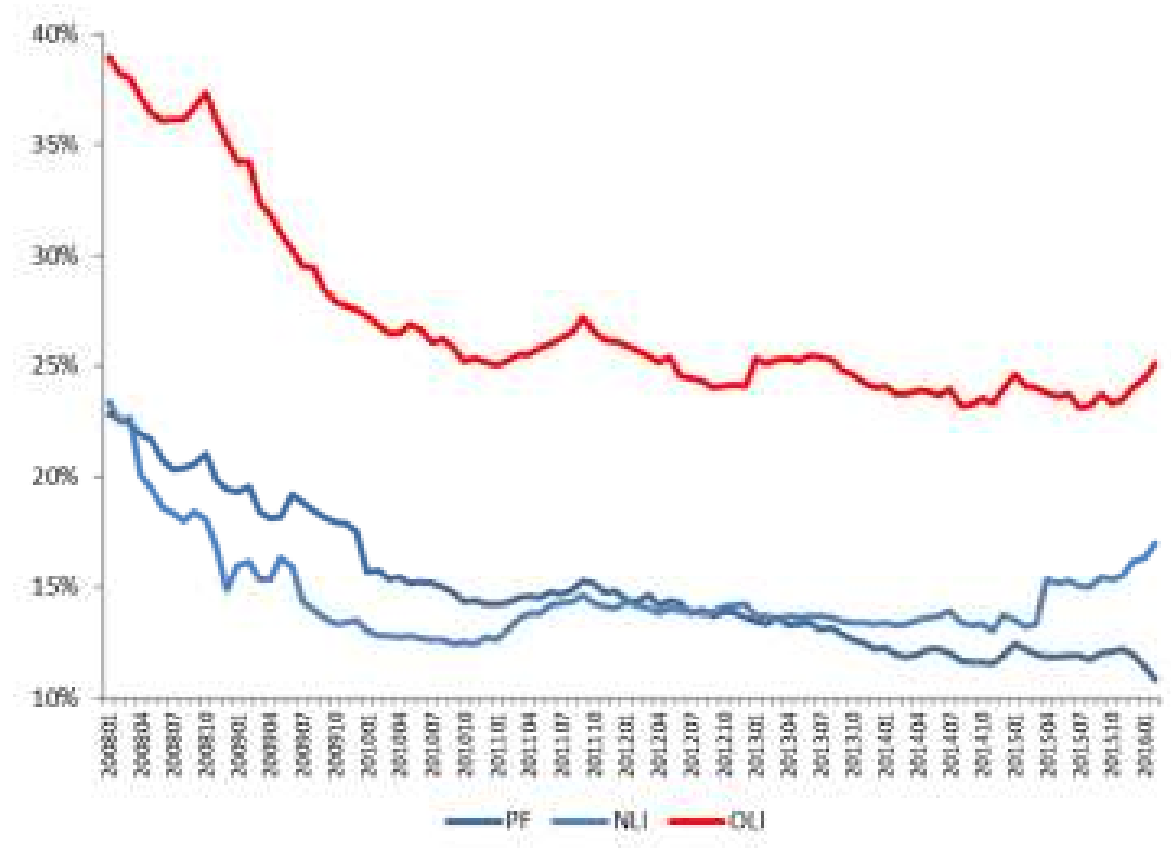

Note: The figures are calculated as the simple average of the allocation of all funds of each type in a given month. 
Figure 2: Estimated $\alpha$ in Old and New Life Insurance Plans

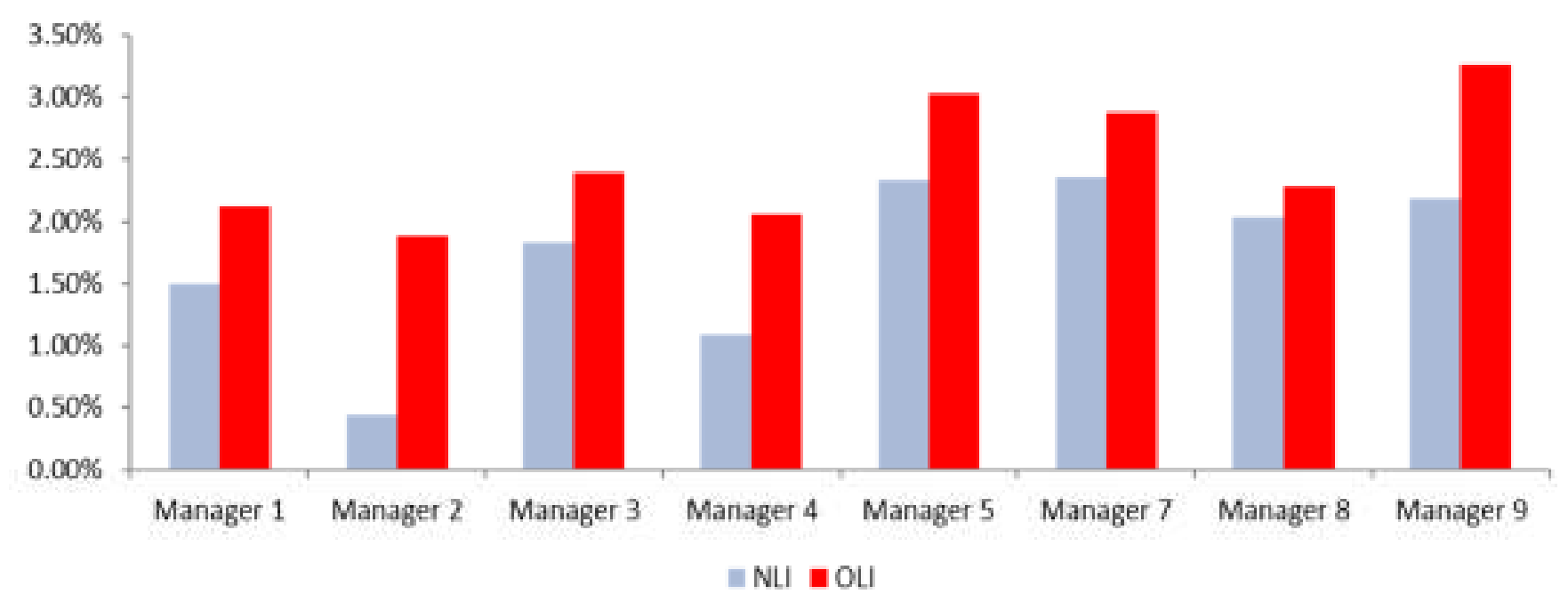

Notes: Average values by fund type and manager. $\alpha$ is estimated using four 36-month periods (1/2005$12 / 2007 ; 1 / 2008-12 / 2010 ; 1 / 2011-12 / 2013$; and 1/2013-12/2015), and expressed in percent in annual terms. Manager 6 has only a NLI plan and is omitted. 